Supporting Information

\title{
Synthesis and Evaluation of Substrate Analogues as Mechanism Based Inhibitors of Type II Isopentenyl Diphosphate Isomerase
}

\author{
Joel R. Walker, Steven C. Rothman and C. Dale Poulter* \\ 315 South 1400 East RM 2020; Department of Chemistry; University of Utah, Salt Lake \\ City, UT, USA 84112 \\ poulter@chemistry.utah.edu
}

Table of Contents

General Methods

S3

Experimental Procedures

S3-S15

IDI2 Inhibition Assays

S15-S17

References

S17

${ }^{1} \mathrm{H}$ NMR spectra for $(E)-7$

S18

${ }^{1} \mathrm{H}$ NMR spectra for $(Z)-7$

$\mathrm{S} 19$

${ }^{1} \mathrm{H}$ and ${ }^{13} \mathrm{C}$ NMR spectra for $(Z)-8$

S20-S21

${ }^{1} \mathrm{H}$ and ${ }^{13} \mathrm{C}$ NMR spectra for $(E)-8$

S22-S23

${ }^{1} \mathrm{H}$ and ${ }^{13} \mathrm{C}$ NMR spectra for (Z)-9-OH

S24-S25

${ }^{1} \mathrm{H}$ and ${ }^{13} \mathrm{C}$ NMR spectra for $(E)-\mathbf{9 - O H}$

S26-S27

${ }^{1} \mathrm{H}$ NMR spectra for (E/Z)-cDMAPP

$\mathrm{S} 28$

${ }^{1} \mathrm{H}$ NMR spectra for 11-OH

S29

${ }^{1} \mathrm{H}$ and ${ }^{13} \mathrm{C}$ NMR spectra for 2

S30-S31

${ }^{1} \mathrm{H}$ and ${ }^{13} \mathrm{C}$ NMR spectra for $\mathbf{3 - O H}$

S32-S33

${ }^{1} \mathrm{H}$ and ${ }^{13} \mathrm{C}$ NMR spectra for Silyl ether 3-OTBS

S34-S35

${ }^{1} \mathrm{H}$ and ${ }^{13} \mathrm{C}$ NMR spectra for $\mathbf{4}$

S36-S37

${ }^{1} \mathrm{H}$ and ${ }^{13} \mathrm{C}$ NMR spectra for 5-OTBS

S38-S39

${ }^{1} \mathrm{H}$ and ${ }^{13} \mathrm{C}$ NMR spectra for $\mathbf{5 - O H}$

S40-S41

${ }^{1} \mathrm{H},{ }^{13} \mathrm{C}$ and ${ }^{31} \mathrm{P}$ NMR spectra for cIPP

S42-S44

${ }^{1} \mathrm{H}$ and ${ }^{13} \mathrm{C}$ NMR spectra for $\mathbf{1 3}$

S45-S46

${ }^{1} \mathrm{H}$ and ${ }^{13} \mathrm{C}$ NMR spectra for 13-OTBS

S47-S48

${ }^{1} \mathrm{H}$ and ${ }^{13} \mathrm{C}$ NMR spectra for Silyl ether 14

S49-S50

${ }^{1} \mathrm{H}$ and ${ }^{13} \mathrm{C}$ NMR spectra for $\mathbf{1 6}$

S51-S52 
${ }^{1} \mathrm{H}$ and ${ }^{13} \mathrm{C}$ NMR spectra for 17-OTBS

S53-S54

${ }^{1} \mathrm{H}$ and ${ }^{13} \mathrm{C}$ NMR spectra for $\mathbf{1 7 - O H}$

S55-S56

${ }^{1} \mathrm{H},{ }^{13} \mathrm{C}$ and ${ }^{31} \mathrm{P}$ NMR spectra for $\mathbf{~ I I P P}$

S57-S59 


\section{General Methods}

Anhydrous solvents were obtained using a standard solvent purification system. TLC was performed on silica gel $0.25 \mathrm{~mm}$ aluminum plates. Silica gel column chromatography was performed with silica gel 60, 230-400 mesh. Cellulose chromatography was performed on CF-11 fibrous cellulose, and cellulose TLC was performed on cellulose F $0.1 \mathrm{~mm}$ plastic sheets. Cellulose TLC plates were visualized by sulfosalicylic acid-ferric chloride stain. NMR spectra were recorded at $300 \mathrm{MHz}\left({ }^{1} \mathrm{H}\right.$ NMR), $75 \mathrm{MHz}\left({ }^{13} \mathrm{C}\right.$ NMR), or $121 \mathrm{MHz}\left({ }^{31} \mathrm{P}\right.$ NMR $) .{ }^{1} \mathrm{H}$ NMR spectra were referenced to residual protons in $\mathrm{CDCl}_{3}(\delta 7.27 \mathrm{ppm})$, DMSO-d $\mathrm{d}_{6}(\delta 2.50 \mathrm{ppm})$, or $\mathrm{D}_{2} \mathrm{O}(\delta 4.80 \mathrm{ppm})$.

${ }^{13} \mathrm{C}$ NMR spectra were referenced to $\mathrm{CDCl}_{3}(\delta 77.00 \mathrm{ppm}), \mathrm{DMSO}-\mathrm{d}_{6}(\delta 2.50 \mathrm{ppm})$, or external $\mathrm{MeOH}(\delta 49.0 \mathrm{ppm})$ in $\mathrm{D}_{2} \mathrm{O} .{ }^{31} \mathrm{P} \mathrm{NMR}$ spectra were referenced to external phosphoric acid ( $\delta 0.00 \mathrm{ppm})$ in $\mathrm{D}_{2} \mathrm{O}$.

\section{Experimental Procedures}

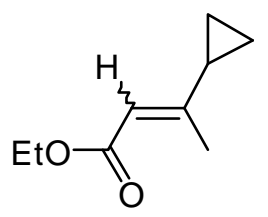

\section{3-Cyclopropyl-but-2-enoic acid ethyl ester. ${ }^{1}$}

A suspension of sodium hydride (60 \% oil dispersion, $2.03 \mathrm{~g}, 50.4 \mathrm{mmol}$ ) and triethyl phosphonoacetate (12.43 g, $55.4 \mathrm{mmol}$ ) in $200 \mathrm{~mL}$ of THF was heated at reflux for $1 \mathrm{~h}$. The mixture was allowed to cool to rt, a solution of $3.88 \mathrm{~g}$ (46.2 mmol) of methylcyclopropyl ketone in $50 \mathrm{~mL}$ of THF was added, and the mixture was heated at reflux overnight. A saturated solution of $\mathrm{NH}_{4} \mathrm{Cl}$ (sat) was added and the mixture was extracted with ether. The organic layer was washed with water and brine, and then the 
aqueous layer was again extracted with ether. The combined extract were dried $\left(\mathrm{MgSO}_{4}\right)$, concentrated at reduced pressure, and chromatographed on silica (7:3 hexanes/ethyl acetate) to give $6.36 \mathrm{~g}$ (89 \%) of an oil. An ${ }^{1} \mathrm{H}$ NMR spectrum indicated a 75:25 mixture of $E$ and $Z$ isomers, in agreement with a previous report. ${ }^{1}$

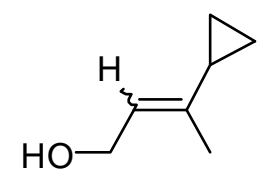

\section{(E)- and (Z)-9-OH.}

A solution of cyclopropyl ester $(1.0 \mathrm{~g}, 6.5 \mathrm{mmol})$ in $100 \mathrm{~mL}$ of ether was cooled to $0{ }^{\circ} \mathrm{C}$ with an ice bath. DIBAL $(1.0 \mathrm{M}, 19.5 \mathrm{~mL}, 19.5 \mathrm{mmol})$ was added slowly via syringe and the mixture was allowed to stir for $3 \mathrm{~h}$ while warming to rt. The mixture was quenched with a saturated solution of $\mathrm{NH}_{4} \mathrm{Cl}$ and extracted with ether. The organic layer was washed with water and brine and the combined aqueous layers were extracted with ether. The combined ether extracts were dried $\left(\mathrm{MgSO}_{4}\right)$, concentrated at reduced pressure, and chromatographed on silica (7:3 hexanes/ethyl acetate) to give $680 \mathrm{mg}$ (93 \%) of an oil. An ${ }^{1} \mathrm{H}$ NMR spectrum indicated that the material was a 75:25 mixture of (E)- and (Z)-9-OH

\section{(E)- and (Z)-7.,3}

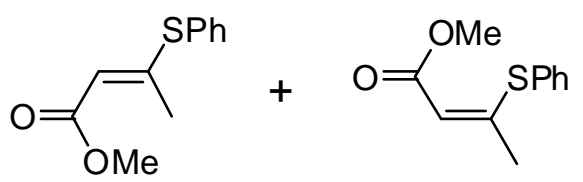

A solution of thiophenol (4.55 g, $41.3 \mathrm{mmol}$ ) and sodium hydroxide (1.65 g, $41.3 \mathrm{mmol})$ in $100 \mathrm{~mL}$ of methanol was allowed to stir for $2 \mathrm{~h}$ at rt. Ethyl-2-butynoate (3.86 g, 34.5 
$\mathrm{mmol}$ ) in $10 \mathrm{~mL}$ of methanol was added and the mixture was allowed to stir for $3 \mathrm{~h}$ before $2.7 \mathrm{~g}$ ( $45 \mathrm{mmol}$ ) of acetic acid were added. The mixture was extracted with ether. The combined ether extracts was washed with water and brine, dried $\left(\mathrm{MgSO}_{4}\right)$ and concentrated at reduced pressure. The residue (6.51 g , 85\%) was chromatographed on silica (hexanes) to give isomeric Michael adducts (E)- 7 (52\%) and (Z)-7 (48\%) separated, $52 \%$ trans (high rf) and $48 \%$ cis (low rf) whose ${ }^{1} \mathrm{H}$ NMR spectra were consistent with those previously reported: $:{ }^{3,4}(E)-7:{ }^{1} \mathrm{H}$ NMR $\left(\mathrm{CDCl}_{3}\right) \delta 2.42(\mathrm{~s}, 3 \mathrm{H}), 3.61$ (s, 3H), 5.22 (s, 1H), 7.40-7.55 (m, 5H); (Z)- 7: ${ }^{1} \mathrm{H}$ NMR $\left(\mathrm{CDCl}_{3}\right) \delta 1.81$ (s, 3H), 3.76 (s, 3H), 5.85 (s, 1H), 7.34-7.58 (m, 5H).

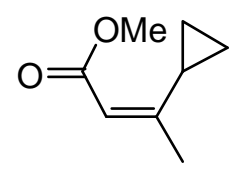

(Z)- 8 .

Copper iodide (1.71 g, $9.0 \mathrm{mmol}$ ) was dried under vacuum for $1 \mathrm{~h}$ placed under $\mathrm{N}_{2}$. THF $(150 \mathrm{~mL})$ was added and the mixture was cooled to $-65^{\circ} \mathrm{C}$. Cyclopropyl magnesium bromide ( $0.5 \mathrm{M}, 45 \mathrm{~mL}, 22.5 \mathrm{mmol}$ ) was added, and after $15 \mathrm{~min}$, a solution

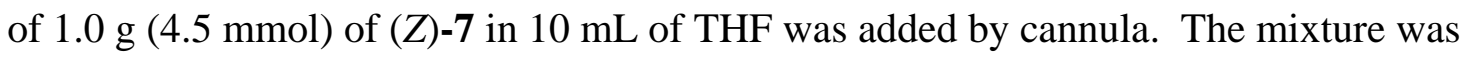
allowed to stir for $3 \mathrm{~h}$ at $-65^{\circ} \mathrm{C}$ before a saturated solution of $\mathrm{NH}_{4} \mathrm{Cl}$ was added while warming to rt. The mixture was extracted with ether. The combined ether extracts were washed with water, $0.2 \mathrm{M} \mathrm{NaOH}$, and brine, dried $\left(\mathrm{MgSO}_{4}\right)$, and concentrated at redued pressure. The residue was chromatographed on silica (9:1 hexanes/ether) to give $593 \mathrm{mg}$ of (94 \%) of an oil; ${ }^{1} \mathrm{H}$ NMR $\left(\mathrm{CDCl}_{3}\right) \delta$ 0.74-0.89 (m, 4H), 1.52 (s, 3H), 3.19-3.25 (m, 
1H), 3.69 (s, 3H), $5.73(\mathrm{~s}, 1 \mathrm{H}) ;{ }^{13} \mathrm{C} \mathrm{NMR}\left(\mathrm{CDCl}_{3}\right) \delta$ 6.7, 13.8, 18.6, 50.7, 115.7, 161.0, 167.5; HRMS (CI) calcd for $\mathrm{C}_{8} \mathrm{H}_{12} \mathrm{O}_{2}(\mathrm{M}+\mathrm{H})$ 141.0915, found 141.0923 .

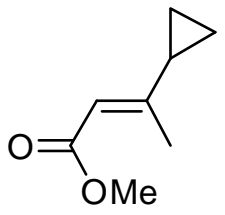

(E)-8.

Following the procedure described for $(Z)-8,1.0 \mathrm{~g}(4.5 \mathrm{mmol})$ of $(E)-7$ gave 561 mg (89 \%) of an oil; ${ }^{1} \mathrm{H}$ NMR $\left(\mathrm{CDCl}_{3}\right) \delta$ 0.65-0.84 (m, 4H), 1.49-1.59 (m, 1H), 1.99 (s, 3H), 3.68 (s, 3H), 5.70 (s, $1 \mathrm{H}) ;{ }^{13} \mathrm{C} \mathrm{NMR}\left(\mathrm{CDCl}_{3}\right) \delta$ 6.8, 15.1, 20.1, 50.7, 112.9, 161.7, 167.1; HRMS (CI) calcd for $\mathrm{C}_{8} \mathrm{H}_{12} \mathrm{O}_{2}(\mathrm{M}+\mathrm{H})$ 141.0915, found 141.0927 .

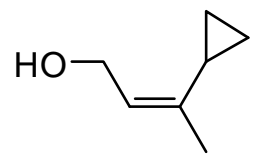

\section{(Z)- 9-OH.}

A solution of $200 \mathrm{mg}(1.4 \mathrm{mmol})$ of $(\mathrm{Z})-\mathbf{8} \mathrm{in} 100 \mathrm{~mL}$ of ether was cooled to $0{ }^{\circ} \mathrm{C}$ before DIBAL (1.0 M, $4.3 \mathrm{~mL}, 4.3 \mathrm{mmol}$ ) was added slowly via syringe. The mixture was allowed to stir for $3 \mathrm{~h}$ while warming to rt. A saturated solution of $\mathrm{NH}_{4} \mathrm{Cl}$ was added and the mixture was extracted with ether. The combined ether extracts were washed with water and brine, dried $\left(\mathrm{MgSO}_{4}\right)$, and concentrated at reduced pressure. The residue was chromatographed on silica (7:3 hexanes/ethyl acetate) to give $135 \mathrm{mg}$ (84 \%) of an oil; ${ }^{1} \mathrm{H}$ NMR $\left(\mathrm{CDCl}_{3}\right) \delta$ 0.55-0.68 (m, 4H), 1.45 (s, 3H), 1.67-1.74 (m, 1H), 4.28 (d, 2H, $J=$ 
$6.9 \mathrm{~Hz}), 5.50(\mathrm{t}, 1 \mathrm{H}, J=6.9 \mathrm{~Hz}) ;{ }^{13} \mathrm{C} \mathrm{NMR}\left(\mathrm{CDCl}_{3}\right) \delta 4.3,12.3,18.6,58.7,124.5,139.6$;

HRMS (EI) calcd for $\mathrm{C}_{7} \mathrm{H}_{12} \mathrm{O}(\mathrm{M}+)$ 112.0888, found 112.0887 .

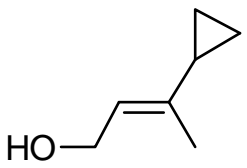

(E)- 9-OH.

Following the procedure described for (Z)-9-OH, $200 \mathrm{mg}(1.4 \mathrm{mmol})$ of $(Z)-\mathbf{8}$ were reduced with DIBAL to give $136 \mathrm{mg}(85 \%)$ of an oil; ${ }^{1} \mathrm{H}$ NMR $\left(\mathrm{CDCl}_{3}\right) \delta 0.46-$ $0.63(\mathrm{~m}, 4 \mathrm{H}), 1.37-1.43(\mathrm{~m}, 1 \mathrm{H}), 1.56$ (s, 3H), 4.15 (d, 2H, $J=6.9 \mathrm{~Hz}), 5.46$ (t, 1H, $J=$ $6.9 \mathrm{~Hz}) ;{ }^{13} \mathrm{C} \mathrm{NMR}\left(\mathrm{CDCl}_{3}\right) \delta 4.6,13.8,18.6,59.1,121.7,140.3$; HRMS (EI) calcd for $\mathrm{C}_{7} \mathrm{H}_{12} \mathrm{O}(\mathrm{M}+)$ 112.0888, found 112.0886.

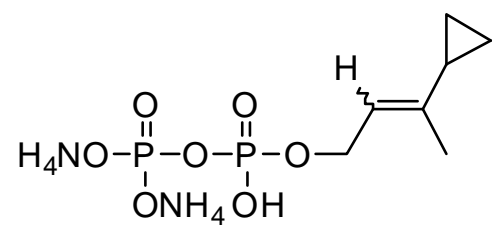

\section{(E/Z)-cDMAPP.}

Trichloroacetonitrile (1.66 mL, $16.6 \mathrm{mmol}$ ) was added to a 75:25 mixture of (E/Z)-9-OH (62 mg, $0.55 \mathrm{mmol}$ ) in $10 \mathrm{~mL}$ of acetonitrile, followed by $0.94 \mathrm{~g}(2.8 \mathrm{mmol})$ of bis(tetra-n-butylammonium) phosphate in $10 \mathrm{~mL}$ of acetonitrile. The reaction was allowed to stir for $2 \mathrm{~h}$ at rt before $3 \mathrm{~mL}$ of $1 \mathrm{M} \mathrm{NH}_{4} \mathrm{HCO}_{3}$ were added. Acetonitrile was removed at reduced pressure. The residue was suspended in $25 \mathrm{mM} \mathrm{NH}_{4} \mathrm{HCO}_{3}: 2 \%$ IPA and loaded onto an ion exchange column (DOW-EX 50W NH${ }_{4}^{+}$form). The column was washed with two column volumes of $25 \mathrm{mM} \mathrm{NH}_{4} \mathrm{HCO}_{3}: 2 \%$ IPA. The eluent was 
lyophilized and the residue was chromatographed on silica (6:3:1 IPA/ $\mathrm{NH}_{4} \mathrm{OH}$

(conc) $/ \mathrm{H}_{2} \mathrm{O}$ ) to give a white powder; ${ }^{1} \mathrm{H}$ NMR $\left(\mathrm{D}_{2} \mathrm{O}\right) \delta$ 0.47-0.64 (m, 4H), $1.41(\mathrm{~s}, 3 \mathrm{H}$, cis- $\left.\mathrm{CH}_{3}\right), 1.43-1.48(\mathrm{~m}, 1 \mathrm{H}$, trans- $\mathrm{CH}), 1.50$, (s, 3H, trans- $\left.\mathrm{CH}_{3}\right), 1.73-1.85(\mathrm{~m}, 1 \mathrm{H}$, cis$\mathrm{CH}), 4.41$ (t, $2 \mathrm{H}, J=6.9 \mathrm{~Hz}$, trans- $\mathrm{CH}_{2}$ ), 4.55 (t, $2 \mathrm{H}, J=6.9 \mathrm{~Hz}$, cis- $\left.\mathrm{CH}_{2}\right), 5.48$ (t, $1 \mathrm{H}, J$ $=6.9 \mathrm{~Hz}) ;{ }^{31} \mathrm{P}$ NMR $\left(\mathrm{D}_{2} \mathrm{O}\right) \delta-5.45(\mathrm{~d}, J=22.0 \mathrm{~Hz}),-18.54(\mathrm{~d}, J=22.0 \mathrm{~Hz})$. cDMAPP was unstable, with a half life at rt of $5 \mathrm{~h}(\mathrm{pH} 8)$ or $10 \mathrm{~h}$ ( $\mathrm{pH}$ 11). The yield of diphosphate (16\%) was determined by phosphate analysis. ${ }^{4}$

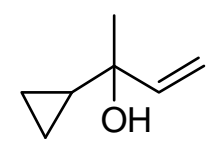

\section{1-OH. ${ }^{5}$}

After standing in $\mathrm{D}_{2} \mathrm{O}$ overnight at rt, cDMAPP solvolyzed to give 11-OH; ${ }^{1} \mathrm{H}$ NMR $\left(\mathrm{D}_{2} \mathrm{O}\right) \delta$ 0.23-0.42 (m, 4H), 0.96-1.05 (m, 1H), 1.20 (s, 3H), 5.06 (dd, $1 \mathrm{H}, J=1.5$, $10.8 \mathrm{~Hz}$ ), 5.17 (dd, $1 \mathrm{H}, J=1.5,17.5 \mathrm{~Hz}), 5.81$ (dd, $1 \mathrm{H}, J=10.8,17.5 \mathrm{~Hz}$ ).

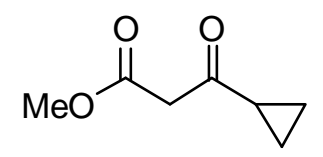

\section{Methyl ester 2.}

Carbonyldiimidazole (10.4 g, $64.4 \mathrm{mmol}$ ) was added in batches over $10 \mathrm{~min}$ to a solution of cyclopropane carboxylic acid $(4.62 \mathrm{~g}, 53.6 \mathrm{mmol})$ in $75 \mathrm{~mL}$ of THF. The mixture was allowed to stir for $45 \mathrm{~min}$ at $0{ }^{\circ} \mathrm{C}$ and $15 \mathrm{~min}$ at rt. Separately, butyl magnesium (1.0 M, $32.2 \mathrm{~mL}, 32.2 \mathrm{mmol}$ ) was added to a solution of monomethyl malonate $(7.60 \mathrm{~g}, 64.4 \mathrm{mmol})$ in $200 \mathrm{~mL}$ of THF at $78{ }^{\circ} \mathrm{C}$. After $45 \mathrm{~min}$ at rt, the 
imidazole conjugate was added to magnesium monomethyl malonate over a period of $1 \mathrm{~h}$. The mixture was allowed to stir for $16 \mathrm{~h}$ at rt. Solvent was removed at reduced pressure and the residue was suspended in ethyl acetate. The organic layer was washed in succession with $1.2 \mathrm{M} \mathrm{HCl}$, a saturated solution of $\mathrm{NaHCO}_{3}$, and brine, dried $\left(\mathrm{MgSO}_{4}\right)$, and concentrated at reduced pressure. The residue was chromatographed on silica (8:2 hexanes/ethyl acetate) to give $5.38 \mathrm{~g}(70 \%)$ of an oil; ${ }^{1} \mathrm{H} \mathrm{NMR}\left(\mathrm{CDCl}_{3}\right) \delta$ 0.93-0.99 (m,

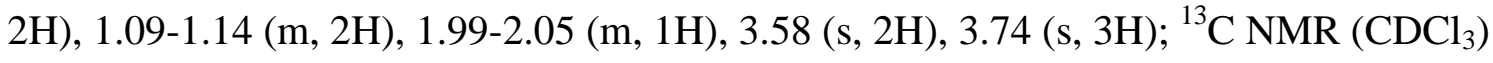
$\delta$ 11.7, 20.7, 49.5, 52.2, 167.6, 202.7; HRMS (CI) calcd for $\mathrm{C}_{7} \mathrm{H}_{10} \mathrm{O}_{3}(\mathrm{M}+\mathrm{H})$ 143.0708, found 143.0704 .

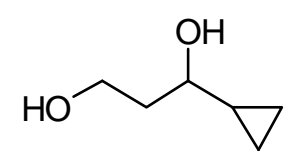

\section{Diol 3-OH.}

A solution of ester $2(2.53 \mathrm{~g}, 17.8 \mathrm{mmol})$ in $250 \mathrm{~mL}$ of 9:1(v/v) methanol/ $\mathrm{H}_{2} \mathrm{O}$ was cooled to $0{ }^{\circ} \mathrm{C}$ before $4.05 \mathrm{~g}$ ( $\left.0.11 \mathrm{~mol}\right)$ of sodium borohydride was added over $1 \mathrm{~h}$. The mixture was allowed to stir for $24 \mathrm{~h}$, was concentrated at reduced pressure to $50 \mathrm{~mL}$, and poured into an ether/brine mixture. After continuous extraction for $48 \mathrm{~h}$, the organic layer was dried $\left(\mathrm{MgSO}_{4}\right)$ and concentrated at reduced pressure. The residue was chromatographed (ethyl acetate) to give $1.87 \mathrm{~g}(90 \%)$ of an oil; ${ }^{1} \mathrm{H} \mathrm{NMR}\left(\mathrm{CDCl}_{3}\right) \delta$ 0.18-0.21 (m, 1H), 0.29-0.35 (m, 1H), 0.48-0.56 (m, 2H), 0.92-1.02 (m, 1H), 1.83-2.04 (m, 2H), 3.07-3.14 (m, 1H), 3.77-3.94 (m, 2H); ${ }^{13} \mathrm{C} \mathrm{NMR}\left(\mathrm{CDCl}_{3}\right) \delta$ 2.2, 2.9, 17.7, 38.1, 61.2, 76.6; HRMS (CI) calcd for $\mathrm{C}_{6} \mathrm{H}_{12} \mathrm{O}_{2}(\mathrm{M}+\mathrm{H})$ 117.0915, found 117.0909. 


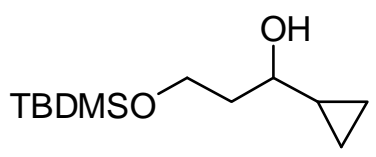

\section{Silyl ether 3-OTBS.}

A solution of tert-butyldimethylsilyl chloride (404 mg, $2.7 \mathrm{mmol})$ in $5 \mathrm{~mL}$ of THF was slowly added to a solution of diol 3-OH (282 mg, $2.4 \mathrm{mmol})$ in $50 \mathrm{~mL}$ of THF, followed by DMAP (10 mg) and imidazole (332 $\mathrm{mg}, 4.9 \mathrm{mmol})$ at $-78{ }^{\circ} \mathrm{C}$, The mixture was allowed to stir at $4{ }^{\circ} \mathrm{C}$ for $16 \mathrm{~h}$ and then for $2 \mathrm{~h}$ at rt. The mixture was extracted with ether and the combined extracts were dried $\left(\mathrm{MgSO}_{4}\right)$ and concentrated at reduced pressure. The residue was chromatographed on silica (8:2 hexanes/ethyl acetate) to give 520 mg (93 \%) of an oil; ${ }^{1} \mathrm{H}$ NMR $\left(\mathrm{CDCl}_{3}\right) \delta 0.07$ (s, 6H), 0.12-0.20 (m, 1H), 0.33-0.91 (m, 4H), 0.89 (s, 9H), 1.78-1.84 (m, 2H), 3.07-3.14 (m, 1H), 3.76-3.95 (m, 2H); ${ }^{13} \mathrm{C}$ NMR $\left(\mathrm{CDCl}_{3}\right) \delta$-5.7, 1.7, 2.7, 17.3, 18.0, 25.7, 38.3, 62.4, 76.5; HRMS (CI) calcd for $\mathrm{C}_{12} \mathrm{H}_{26} \mathrm{O}_{2} \mathrm{Si}(\mathrm{M}+\mathrm{H})$ 231.1780, found 231.1783.

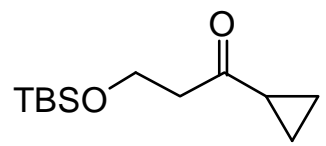

\section{Ketone 4.}

Dess-Martin periodinane (15 \% wt, $9.5 \mathrm{~g}, 3.4 \mathrm{mmol}$ ) was added to a solution of 3OTBS (515 mg, $2.2 \mathrm{mmol}$ ) in $100 \mathrm{~mL}$ of methylene chloride. After $2 \mathrm{~h}$, a solution of saturated $\mathrm{NaHCO}_{3}$ and solid $\mathrm{Na}_{2} \mathrm{~S}_{2} \mathrm{O}_{3}$ were added. After 15 min the mixture was extracted with ether and the combined extracts were washed with brine. The extracts were dried $\left(\mathrm{MgSO}_{4}\right)$ and concentrated at reduced pressure. The residue was chromatographed on silica (8:2 hexanes/ethyl acetate) to give $447 \mathrm{mg}$ (87\%) of an oil; 
${ }^{1} \mathrm{H}$ NMR $\left(\mathrm{CDCl}_{3}\right) \delta 0.05$ (s, 6H), 0.84-0.90 (m, 2H), 0.88 (s, 9H), 1.01-1.06 (m, 2H), 1.95-2.00 (m, 1H), 2.74 (t, 2H, $J=6.6 \mathrm{~Hz}), 3.91(\mathrm{t}, 2 \mathrm{H}, J=6.6 \mathrm{~Hz}) ;{ }^{13} \mathrm{C} \mathrm{NMR}\left(\mathrm{CDCl}_{3}\right)$ $\delta$-5.5, 10.7, 18.2, 21.0, 25.8, 46.1, 58.9, 209.8; HRMS (CI) calcd for $\mathrm{C}_{12} \mathrm{H}_{24} \mathrm{O}_{2} \mathrm{Si}(\mathrm{M}+\mathrm{H})$ 229.1624, found 229.1621.

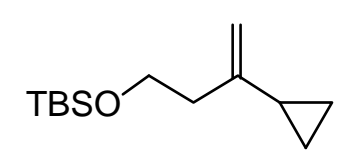

\section{5-OTBS.}

Tebbe reagent ( $0.5 \mathrm{M}, 3.0 \mathrm{~mL}, 1.5 \mathrm{mmol}$ ) was added to a solution of ketone 4 (340 mg, $1.5 \mathrm{mmol}$ ) in $50 \mathrm{~mL}$ of $\mathrm{THF}$ at $0{ }^{\circ} \mathrm{C}$. The mixture was allowed to stir at $0{ }^{\circ} \mathrm{C}$ for $30 \mathrm{~min}$ and then allowed to warm to rt. The mixture was diluted with ether, $0.1 \mathrm{M}$ $\mathrm{NaOH}$ was carefully added until bubbling ceased. The ether extract was dried $\left(\mathrm{MgSO}_{4}\right)$, filtered through celite and concentrated at reduced pressure. The residual orange oil was chromatographed (9:1 hexanes/ethyl acetate) to give $300 \mathrm{mg}$ (88 \%) of an oil; ${ }^{1} \mathrm{H}$ NMR $\left(\mathrm{CDCl}_{3}\right) \delta 0.07$ (s, 6H), 0.40-0.46 (m, 2H), 0.59-0.65 (m, 2H), 0.89 (s, 9H), 1.28-1.33 (m, 1H), 2.25 (td, 2H, $J=7.2 \mathrm{~Hz}$ ), 3.74 (t, 2H, $J=7.2 \mathrm{~Hz}), 4.64-4.68(\mathrm{~m}, 2 \mathrm{H}) ;{ }^{13} \mathrm{C} \mathrm{NMR}$ $\left(\mathrm{CDCl}_{3}\right) \delta$-5.3, 6.0, 16.3, 18.3, 26.0, 39.2, 62.7, 107.9, 147.86; HRMS (CI) calcd for $\mathrm{C}_{13} \mathrm{H}_{26} \mathrm{OSi}(\mathrm{M}+\mathrm{H})$ 227.1831, found 227.1835. 


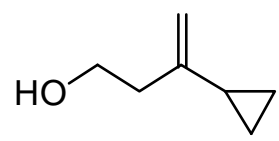

5-OH.

TBAF (1.0 M, $4.0 \mathrm{~mL}, 4.0 \mathrm{mmol}$ ) was added to a solution of 5-OTBS (300 mg, $1.3 \mathrm{mmol}$ ) in $25 \mathrm{~mL}$ of $\mathrm{THF}$ at $0^{\circ} \mathrm{C}$ and allowed to stir for $30 \mathrm{~min}$ and then at rt for $1 \mathrm{~h}$. The mixture was diluted with ethyl acetate and washed with water and brine. The aqueous layers were extracted with ethyl acetate and the combined organic extracts were dried $\left(\mathrm{MgSO}_{4}\right)$ and concentrated at reduced pressure. The residue was chromatographed (7:3 hexanes/ethyl acetate) to give $116 \mathrm{mg}(76 \%)$ of an oil; ${ }^{1} \mathrm{H} \mathrm{NMR}\left(\mathrm{CDCl}_{3}\right) \delta$ 0.450.49 (m, 2H), 0.64-0.68 (m, 2H), 1.26-1.33 (m, 1H), 2.33 (td, 2H, J = 1.2, $6.3 \mathrm{~Hz}), 3.77$ (t, 2H, 6.3 Hz), 4.72-4.76 (m, 2H); ${ }^{13} \mathrm{C} \mathrm{NMR}\left(\mathrm{CDCl}_{3}\right) \delta$ 6.1, 15.7, 39.2, 60.7, 108.6, 147.3; HRMS (CI) calcd for $\mathrm{C}_{7} \mathrm{H}_{12} \mathrm{O}(\mathrm{M}+\mathrm{H})$ 113.0966, found 113.0969 .

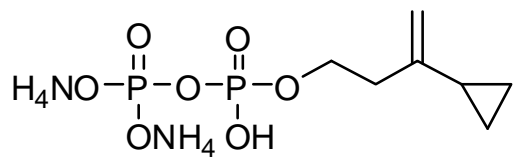

CIPP.

A solution of 5-OH (34 mg, $0.30 \mathrm{mmol}$ ) in $2 \mathrm{~mL}$ of methylene chloride was added dropwise to p-toluenesulfonyl chloride (57 mg, $0.30 \mathrm{mmol}$ ) and DMAP (44 mg, $0.36 \mathrm{mmol}$ ) in $10 \mathrm{~mL}$ of methylene chloride. cannula. The reaction was allowed to stir at rt for $16 \mathrm{~h}$, solvent was removed at reduced pressure and the residue was chromatographed on silica (8:2 hexanes/ethyl acetate) to give $53 \mathrm{mg}$ (66 \%) of an oil. The tosylate was used in the next step without characterization. 
A solution of the tosylate $(37 \mathrm{mg}, 0.14 \mathrm{mmol}$ ) in $2 \mathrm{~mL}$ of acetonitrile was added dropwise to tris-(tetra-butylammonium) pyrophosphate trihydrate (408 mg, $0.42 \mathrm{mmol}$ ) in $10 \mathrm{~mL}$ of acetonitrile. The mixture was allowed to stir at $\mathrm{rt}$ for $3 \mathrm{~h}$ and concentrated at reduced pressure. The residue was loaded onto an ion exchange column (DOW-EX 50W $\mathrm{NH}_{4}{ }^{+}$form) with $25 \mathrm{mM} \mathrm{NH}_{4} \mathrm{HCO}_{3}: 2 \%$ IPA (v/v). The column was eluted with two column volumes of $25 \mathrm{mM} \mathrm{NH}_{4} \mathrm{HCO}_{3}: 2 \%$ IPA (v/v). The eluent was lyophilized and the residue was chromatographed on silica (6:3:1 IPA/ $\mathrm{NH}_{4} \mathrm{OH}$ (conc)/ $\mathrm{H}_{2} \mathrm{O}$ ) to give white powder; ${ }^{1} \mathrm{H}$ NMR $\left(\mathrm{D}_{2} \mathrm{O}\right) \delta$ 0.45-0.48 (m, 2H), 0.61-0.65 (m, 2H), 1.33-1.37 (m, 1H), $2.36(\mathrm{t}, 2 \mathrm{H}, J=6.9 \mathrm{~Hz}), 4.06(\mathrm{q}, 2 \mathrm{H}, J=6.9 \mathrm{~Hz}) ;{ }^{13} \mathrm{C} \operatorname{NMR}\left(\mathrm{D}_{2} \mathrm{O}\right) \delta 6.3,16.3,36.5,65.3$, 108.5, 149.5; ${ }^{31} \mathrm{P}$ NMR $\left(\mathrm{D}_{2} \mathrm{O}\right) \delta-6.45(\mathrm{~d}, J=22.0 \mathrm{~Hz}),-10.42(\mathrm{~d}, J=22.0 \mathrm{~Hz})$; HRMS (CI) calcd for $\mathrm{C}_{7} \mathrm{H}_{14} \mathrm{O}_{7} \mathrm{P}_{2}(\mathrm{M}-\mathrm{H})$ 271.0127, found 271.0137. The yield (17 \%) determined by phosphate analysis. ${ }^{4}$

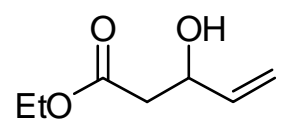

\section{Ethyl ester $12{ }^{6}$}

Butyl lithium (2.5 M, $8.4 \mathrm{~mL}, 21 \mathrm{mmol}$ ) was added to a solution of diisopropyl amine $(2.12 \mathrm{~g}, 3.0 \mathrm{~mL}, 21 \mathrm{mmol})$ in $100 \mathrm{~mL}$ of $\mathrm{THF}$ at $-78^{\circ} \mathrm{C}$. After $15 \mathrm{~min}$ a solution of anhydrous ethyl acetate $(1.57 \mathrm{~g}, 1.8 \mathrm{~mL}, 17.8 \mathrm{mmol})$ in $5 \mathrm{~mL}$ of THF was added and the mixture was allowed to stir at $-78{ }^{\circ} \mathrm{C}$ for $50 \mathrm{~min}$. A solution of acrolein (1.0 g, 17.8 mmol) in $10 \mathrm{~mL}$ of THF was added slowly and stirring was continued for $5 \mathrm{~min}$. A saturated solution of $\mathrm{NH}_{4} \mathrm{Cl}$ was added and the mixture was allowed to warm to rt. The mixture was diluted with ether and washed with water and brine. The aqueous layers were extracted with ether and the combined organic layers were dried $\left(\mathrm{MgSO}_{4}\right)$ and 
concentrated at reduced pressure. The residue was chromatographed on silica (75:25 hexanes/ethyl acetate) to give $1.62 \mathrm{~g}(63 \%)$ of an oil. ${ }^{1} \mathrm{H}$ NMR spectrum matched with a previous report. ${ }^{6}$

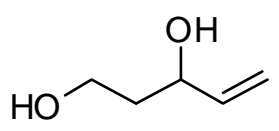

\section{Diol 13.}

Sodium borohydride (1.28 g, $33.7 \mathrm{mmol})$ was carefully added to a solution of $\mathbf{1 2}$ (1.62 g, $11.2 \mathrm{mmol})$ in $\mathrm{MeOH} /$ water $(9: 1,100 \mathrm{~mL})$. The mixture was allowed to stir at rt for $2 \mathrm{~h}$ after which an additional $500 \mathrm{mg}$ of $\mathrm{NaBH}_{4}$ was added and stirring was continued for $18 \mathrm{~h}$. The mixture was concentrated to $\sim 20 \mathrm{~mL}$. Ether and brine were added and the mixture was continuously extracted for 2 days. The organic layer was concentrated at reduced pressure and the residue was chromatographed (1:1 hexanes/ethyl acetate) to give $698 \mathrm{mg}(61 \%)$ of an oil; ${ }^{1} \mathrm{H}$ NMR $\left(\mathrm{CDCl}_{3}\right) \delta 1.75-1.84$ (m, 2H), 3.79-3.91 (m, 2H), 4.37-4.43 (m, 1H), 5.12-5.16 (m, 1H), 5.25-5.32 (m, 1H), 5.865.97 (m, 1H); ${ }^{13} \mathrm{C}$ NMR $\left(\mathrm{CDCl}_{3}\right) \delta$ 38.1, 60.4, 72.0, 114.5, 140.4; HRMS (CI) calcd for $\mathrm{C}_{5} \mathrm{H}_{10} \mathrm{O}_{2}(\mathrm{M}+\mathrm{H})$ 103.0759, found 103.0737.

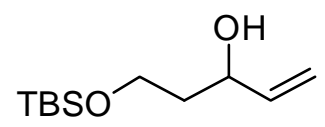

\section{3-OTBS.}

A solution of TBSCl (506 mg, $3.36 \mathrm{mmol}$ ) in $5 \mathrm{~mL}$ of THF was slowly added to a solution of 13 (440 mg, $3.05 \mathrm{mmol}$ ), imidazole (416 mg, $6.1 \mathrm{mmol}$ ), and DMAP (18 mg, $0.15 \mathrm{mmol}$ ) in $50 \mathrm{~mL}$ of $\mathrm{THF}$ at $-78^{\circ} \mathrm{C}$. The reaction was allowed to stir for $18 \mathrm{~h}$ while 
warming to $4{ }^{\circ} \mathrm{C}$. The mixture was extracted with ether and the combined aqueous layers were extracted with ether. The combined ether extracts were dried $\left(\mathrm{MgSO}_{4}\right)$ and concentrated at reduced pressure. The residue was chromatographed on silica (8:2 hexanes/ethyl acetate) to give $617 \mathrm{mg}$ (93\%) of an oil; ${ }^{1} \mathrm{H} \mathrm{NMR}\left(\mathrm{CDCl}_{3}\right) \delta 0.08$ (s, 6H), 0.91 (s, 9H), 1.71-1.79 (m, 2H), 3.77-3.93 (m, 2H), 4.33-4.39 (m, 1H), 5.09-5.13 (m, 1H), 5.25-5.32 (m, 1H), 5.83-5.94 (m, 1H); ${ }^{13} \mathrm{C} \mathrm{NMR}\left(\mathrm{CDCl}_{3}\right) \delta$-5.6, 18.1, 25.8, 61.9, 72.4, 114.1, 140.5; HRMS (CI) calcd for $\mathrm{C}_{11} \mathrm{H}_{24} \mathrm{O}_{2} \mathrm{Si}(\mathrm{M}+\mathrm{H})$ 217.1624, found 217.1622.

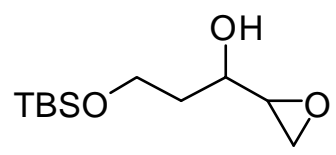

\section{Silyl ether 14.}

A solution of silyl ether 13-OTBS (1.0 g, $4.62 \mathrm{mmol})$ in $5 \mathrm{~mL}$ of $\mathrm{CH}_{2} \mathrm{Cl}_{2}$ was added to $\mathrm{mCPBA}(4.0 \mathrm{~g}, 23.1 \mathrm{mmol})$ in $100 \mathrm{~mL}$ of $\mathrm{CH}_{2} \mathrm{Cl}_{2}$ at $0{ }^{\circ} \mathrm{C}$. The mixture was allowed to stir for $18 \mathrm{~h}$, while warming to rt, before a saturated solution of $\mathrm{Na}_{2} \mathrm{~S}_{2} \mathrm{O}_{3}$ was added. The mixture was diluted with $\mathrm{CH}_{2} \mathrm{Cl}_{2}$ and washed with water and a saturated solution of $\mathrm{NaHCO}_{3}$. The aqueous layers were extracted with $\mathrm{CH}_{2} \mathrm{Cl}_{2}$ and the organic layers were dried $\left(\mathrm{MgSO}_{4}\right)$ and concentrated at reduced pressure. The residue was chromatographed on silica (8:2 hexanes/ethyl acetate) to give $687 \mathrm{mg}$ (64 \%) of an oil as a mixture of diastereomers; ${ }^{1} \mathrm{H}$ NMR $\left(\mathrm{CDCl}_{3}\right) \delta 0.08(\mathrm{~s}, 6 \mathrm{H}), 0.91(\mathrm{~s}, 9 \mathrm{H}), 1.76-1.86(\mathrm{~m}$, 2H), 2.72-2.80 (m, 2H), 2.93 (d, 1H, $J=4.2 \mathrm{~Hz}$ ), 2.98-3.04 (m, 1H), 3.26 (d, 1H, $J=2.1$ Hz), 3.72-3.95 (m, 2H); ${ }^{13} \mathrm{C}$ NMR $\left(\mathrm{CDCl}_{3}\right) \delta$-5.3, 18.3, 25.0, 35.6, 36.2, 44.6, 45.0, 54.5, 55.4, 61.2, 61.7, 70.2, 70.6; HRMS (CI) calcd for $\mathrm{C}_{11} \mathrm{H}_{24} \mathrm{O}_{3} \mathrm{Si}(\mathrm{M}+\mathrm{H})$ 233.1573, found 233.1571. 


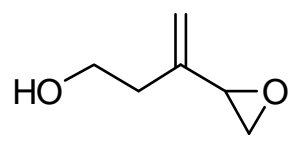

\section{7-OH.}

Triethylamine trihydrofluoride $(0.14 \mathrm{~mL}, 8.5 \mathrm{mmol})$ was added to a solution of $194 \mathrm{mg}$ (0.85 mmol) of silyl ether $14 \mathrm{in} 8 \mathrm{~mL}$ of THF and the mixture was allowed to stir for $2 \mathrm{~d}$. Triethylamine $(0.2 \mathrm{~mL})$ was added and the mixture was concentrated at reduced pressure. The residue was chromatographed on silica (1:1 to 0:1 hexanes/ethyl acetate) to give $70 \mathrm{mg}(72 \%)$ of an oil; ${ }^{1} \mathrm{H}$ NMR $\left(\mathrm{CDCl}_{3}\right) \delta 2.06(\mathrm{~s}, 1 \mathrm{H}), 2.15-2.28(\mathrm{~m}, 2 \mathrm{H}), 2.73-$ 2.76 (m, 1H), 2.89-2.93 (m, 1H), 3.40-3.42 (m, 1H), 3.67-3.72 (m, 2H), 5.10-5.11 (m, 1H), 5.31 (s, 1H); ${ }^{13} \mathrm{C}$ NMR $\left(\mathrm{CDCl}_{3}\right) \delta 33.9,47.4,54.0,61.5,116.0,142.3$; HRMS (CI) calcd for $\mathrm{C}_{6} \mathrm{H}_{10} \mathrm{O}_{2}(\mathrm{M}+\mathrm{H})$ 115.0759, found 115.0777 .

\section{Assays for IDI-2}

The standard acid-lability assay was used to measure initial rates for Thermus thermophilus IDI2. ${ }^{7}$ The following concentrations were used for IC $_{50}$ measurements: 200 mM Tris buffer, pH 7.0, containing 8 nM IDI-2, $5 \mu \mathrm{M}$ IPP (59 $\mu \mathrm{Ci} / \mu \mathrm{mol}), 20 \mu \mathrm{M}$ FMN, $5 \mathrm{mM}$ NADPH, $10 \mathrm{mM} \mathrm{MgCl} 2,50 \mu \mathrm{L}$ total volume, for $10 \mathrm{~min}$ at $37^{\circ} \mathrm{C}$.

Irreversible inhibition of IDI2 was measured as follows: $200 \mathrm{mM}$ Tris buffer, $\mathrm{pH}$ 7.0, 40 nM IDI-2, 40 MM FMN, 2 mM NADPH, 2 mM MgCl 2 , and 500 nM oIPP, 50 $\mu \mathrm{L}$ total volume, for $10 \mathrm{~min}$ at $37^{\circ} \mathrm{C}$. The mixture was incubated for fixed periods of time and then diluted 10 -fold into buffer containing $50 \mu \mathrm{M}$ IPP $(10 \mu \mathrm{Ci} / \mu \mathrm{mol})$. The residual activity was measured by the acid-lability assay. 
The flavin adducts were detected following incubation in $200 \mathrm{mM}$ Tris buffer, $\mathrm{pH}$ 7.0, containing $50 \mu \mathrm{M}$ FMN bound IDI-2, $1 \mathrm{mM}$ oIPP or IPP, $2 \mathrm{mM}$ NADPH, $2 \mathrm{mM}$ $\mathrm{MgCl}_{2}, 100 \mu \mathrm{L}$ total volume for $2 \mathrm{~h}$ at $37^{\circ} \mathrm{C}$. After the incubation, the samples were diluted with $300 \mu \mathrm{L}$ of Tris buffer, applied to a Centricon (10,000 mwco) membrane filter and centrifuged at 11,000 rpm for 25 min. Dilution/centrifugation was repeated twice. The eluent was saved and analyzed by HPLC. The retained solution diluted with $100 \mu \mathrm{L}$ of guanidine buffer (8 M, 10 mM HEPES, pH 7.35) and allowed to incubate for 20 min at rt. The sample was centrifuged again and the filtrate was analyzed by LC-MS. The HPLC conditions were as follows: Nova-Pak C-18 column (3.9 x 150 mm, $60 \AA$, 4 $\mu \mathrm{m}$, part number WAT086344) with elution by 10:90 (v/v) methanol/5 mM ammonium acetate (pH 6.0).

\section{References:}

1. Jorgenson, M. J. J. Am. Chem. Soc. 1969, 91, 6432-6443.

2. Kobayashi, S.; Mukaiyama, T. Chem. Lett. 1974, 1425-1428.

3. Mori, K.; Mori, H. Tetrahedron, 1987, 43, 4097-4106.

4. Hess, H. H.; Derr, J. E. Anal. Biochem. 1975, 63, 607.

5. Babler, J.H.; Coghlan, M.J.; Giacherio, D.J. J. Org. Chem. 1977, 42, 2172-2175.

6. Zibuck, R.; Streiber, J. Org. Synth. 1998, Coll. Vol. 9, 432-435.

7. Rothman, S. C.; Helm, T. R.; Poulter, C. D. Biochemistry 2007, 46, 5437-5445. 


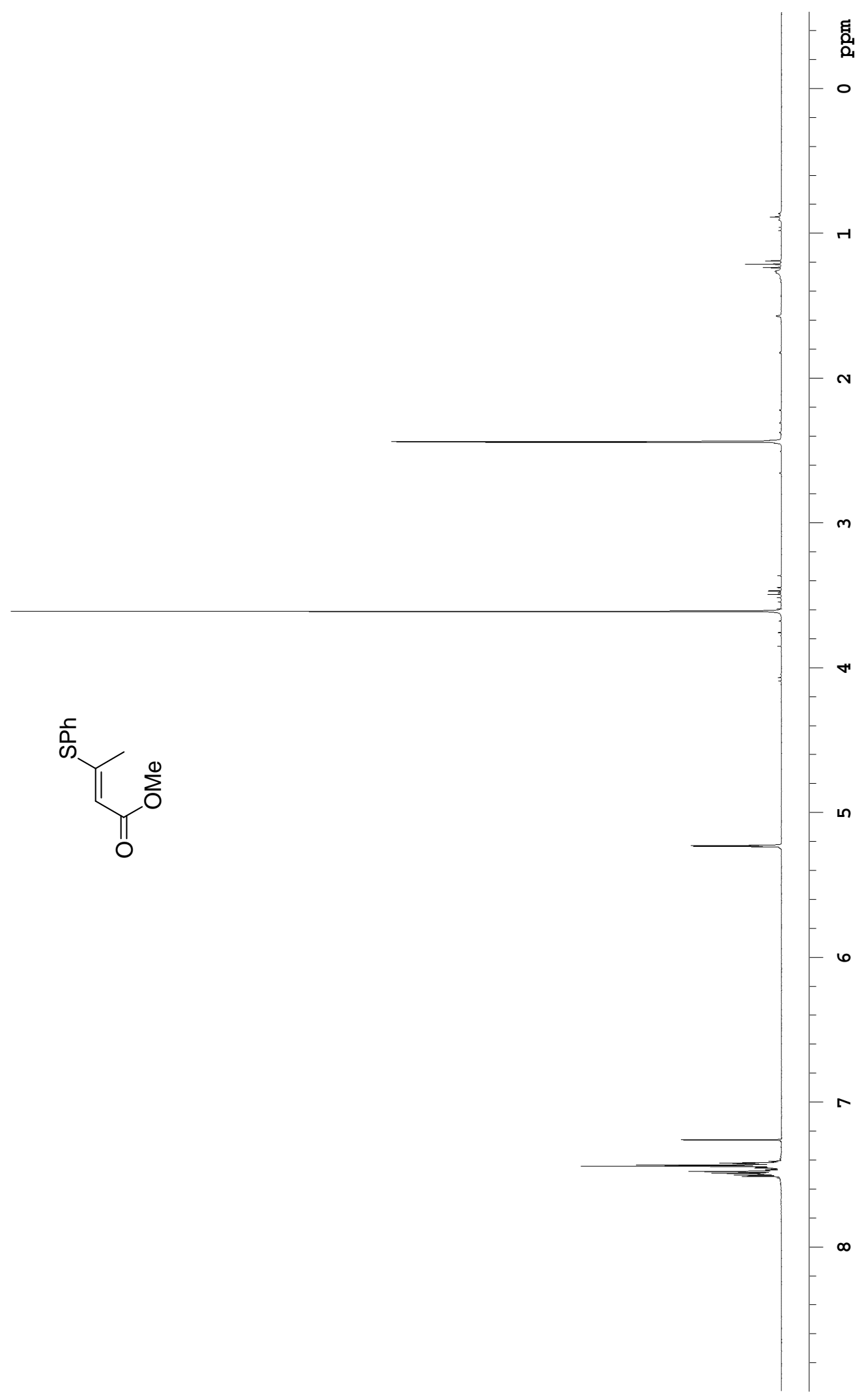




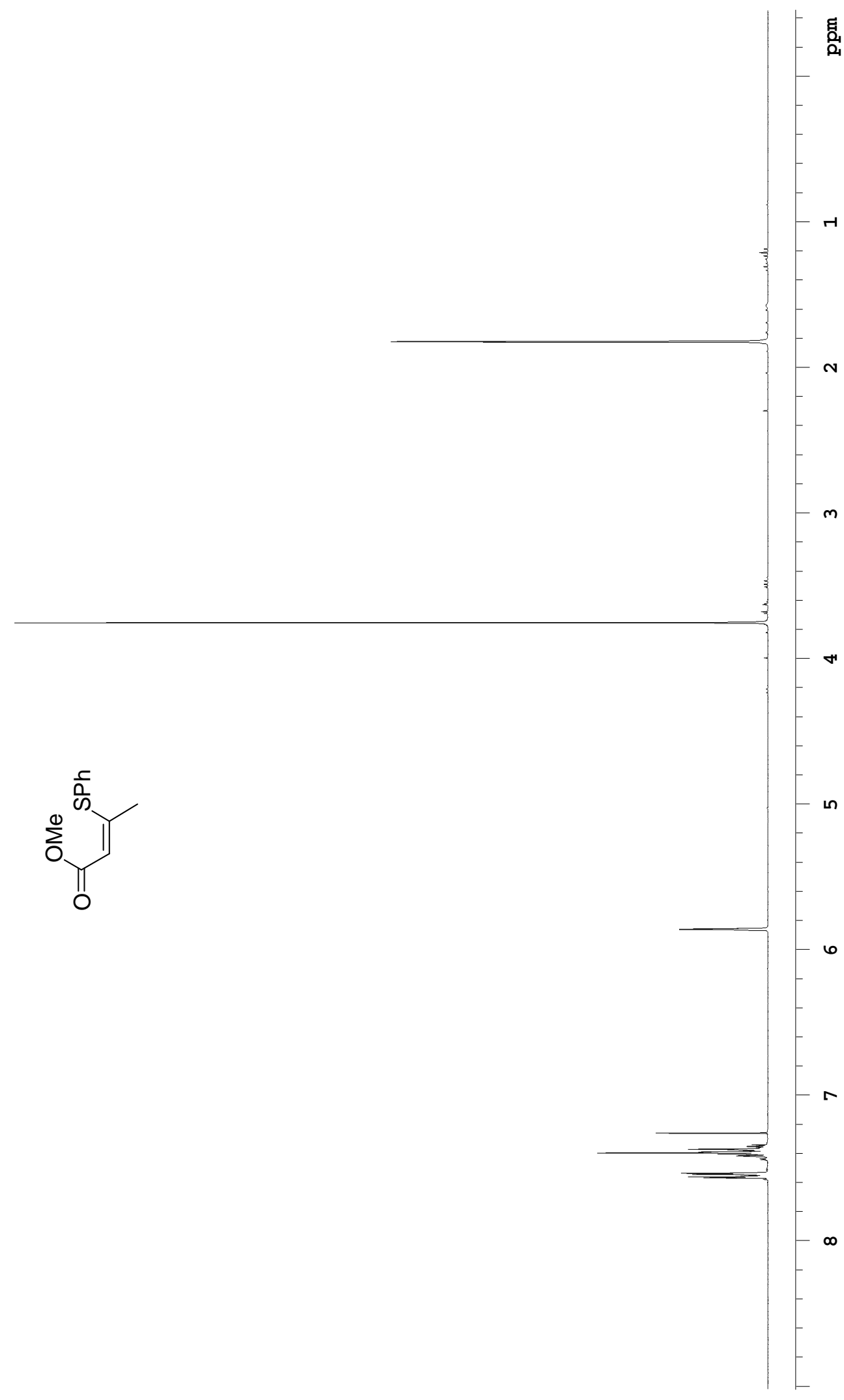




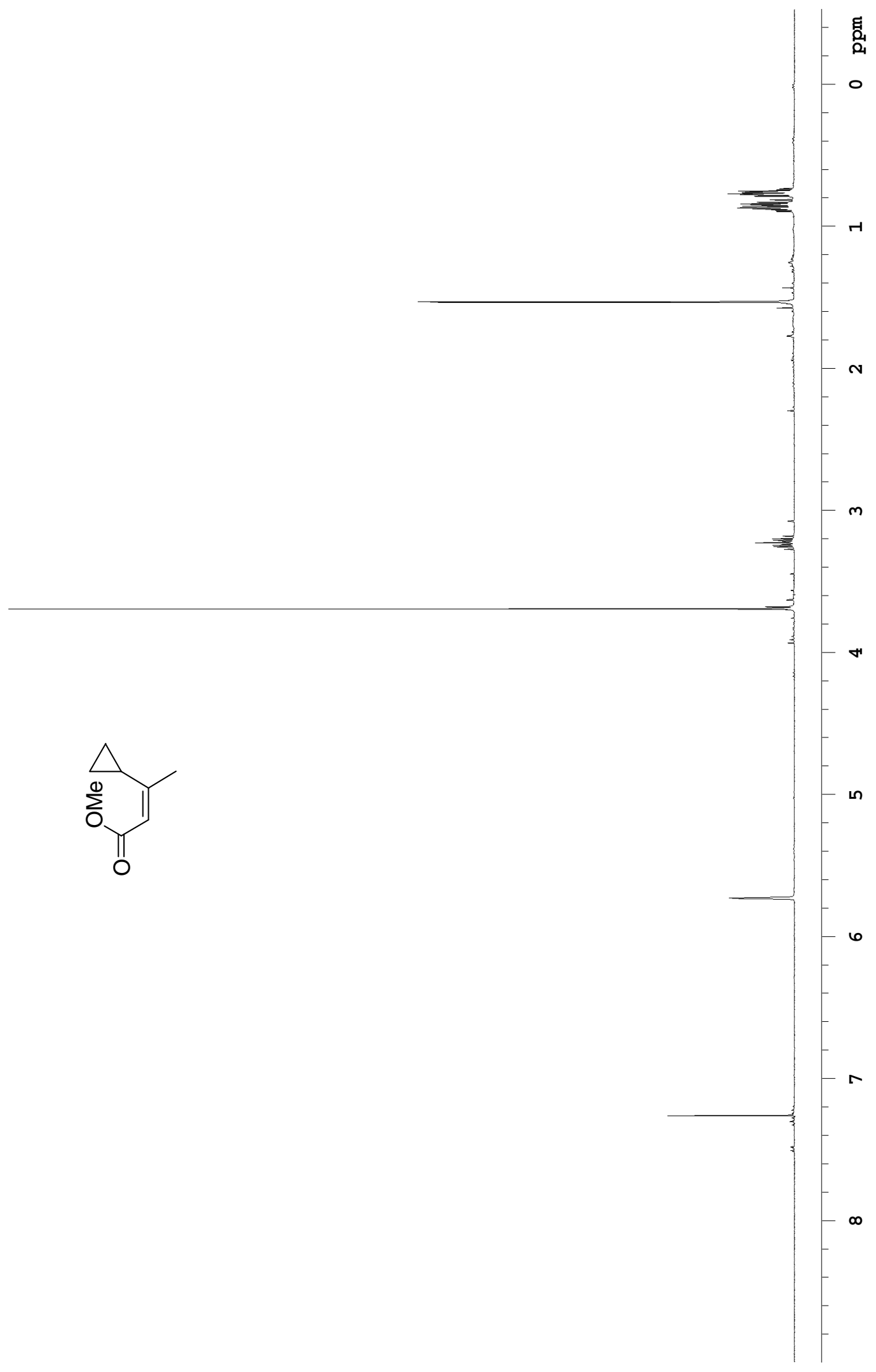




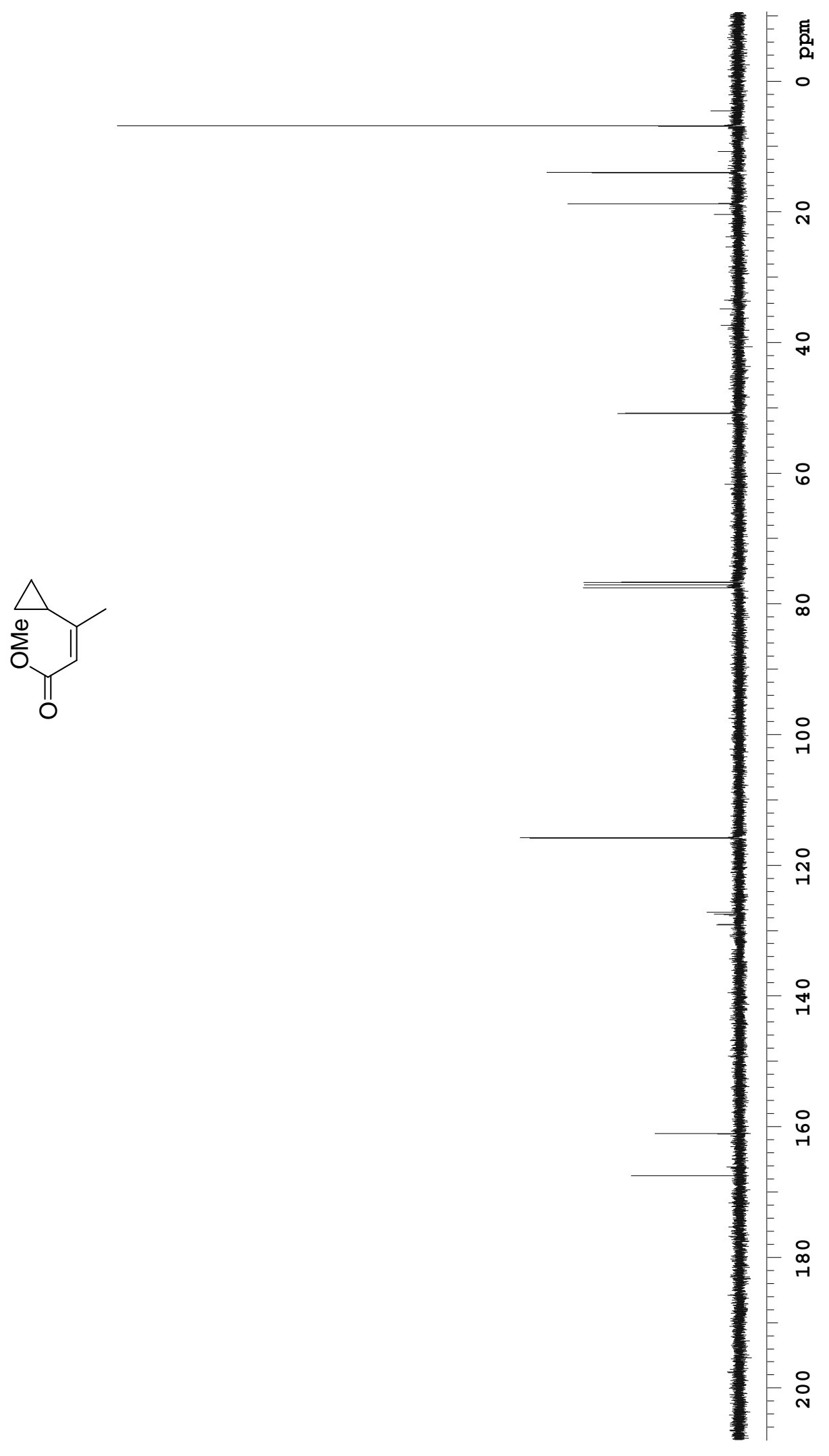




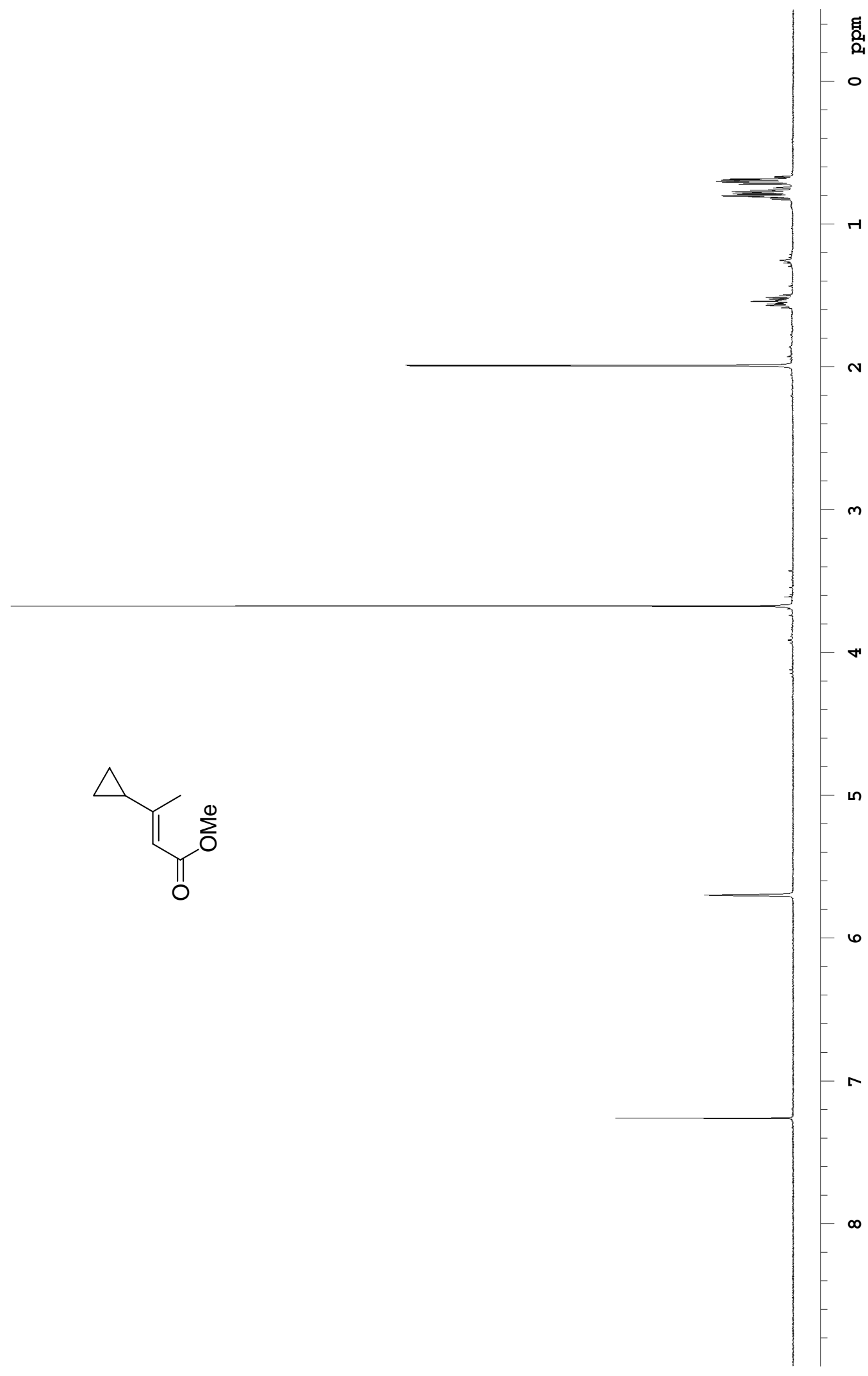




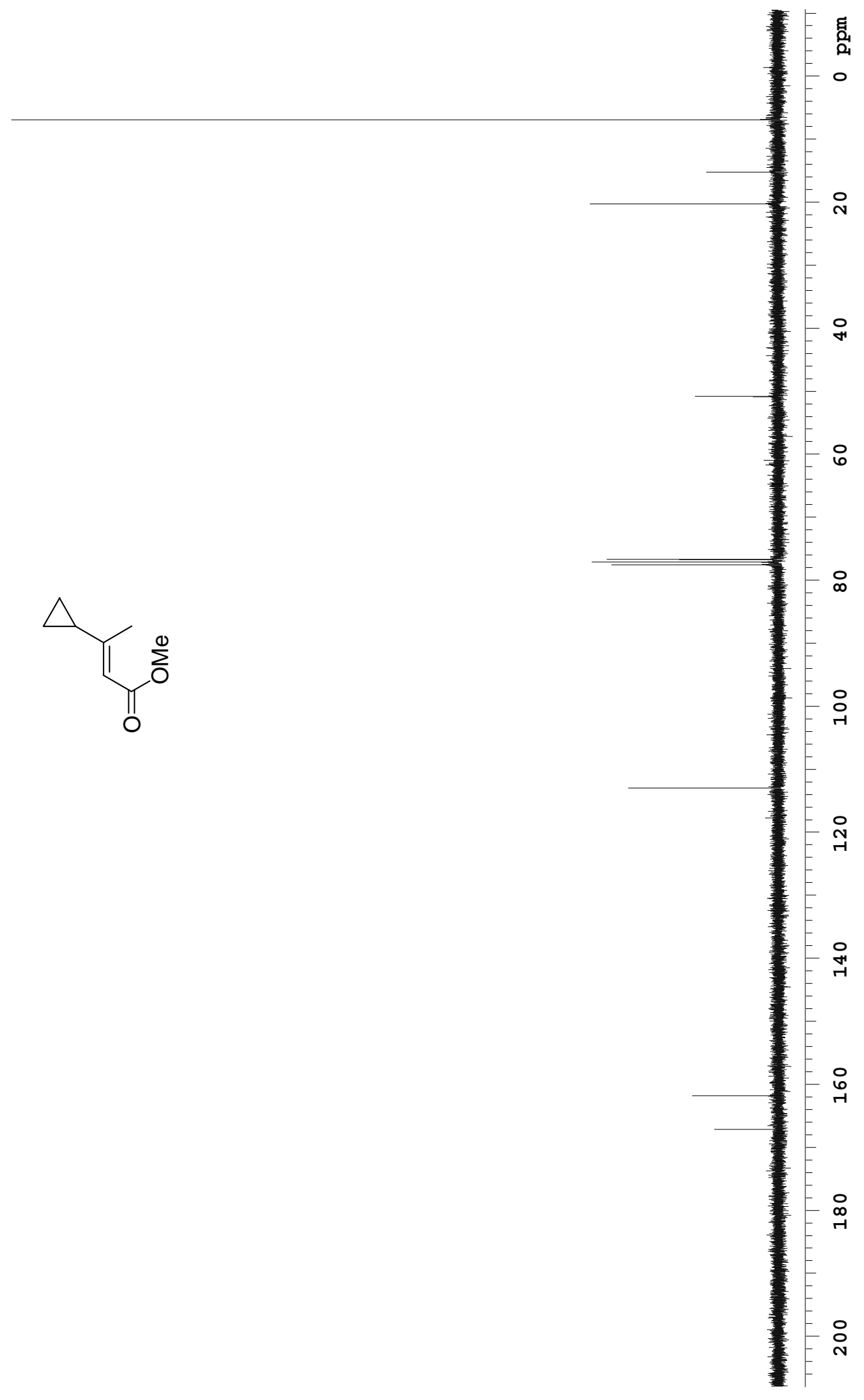




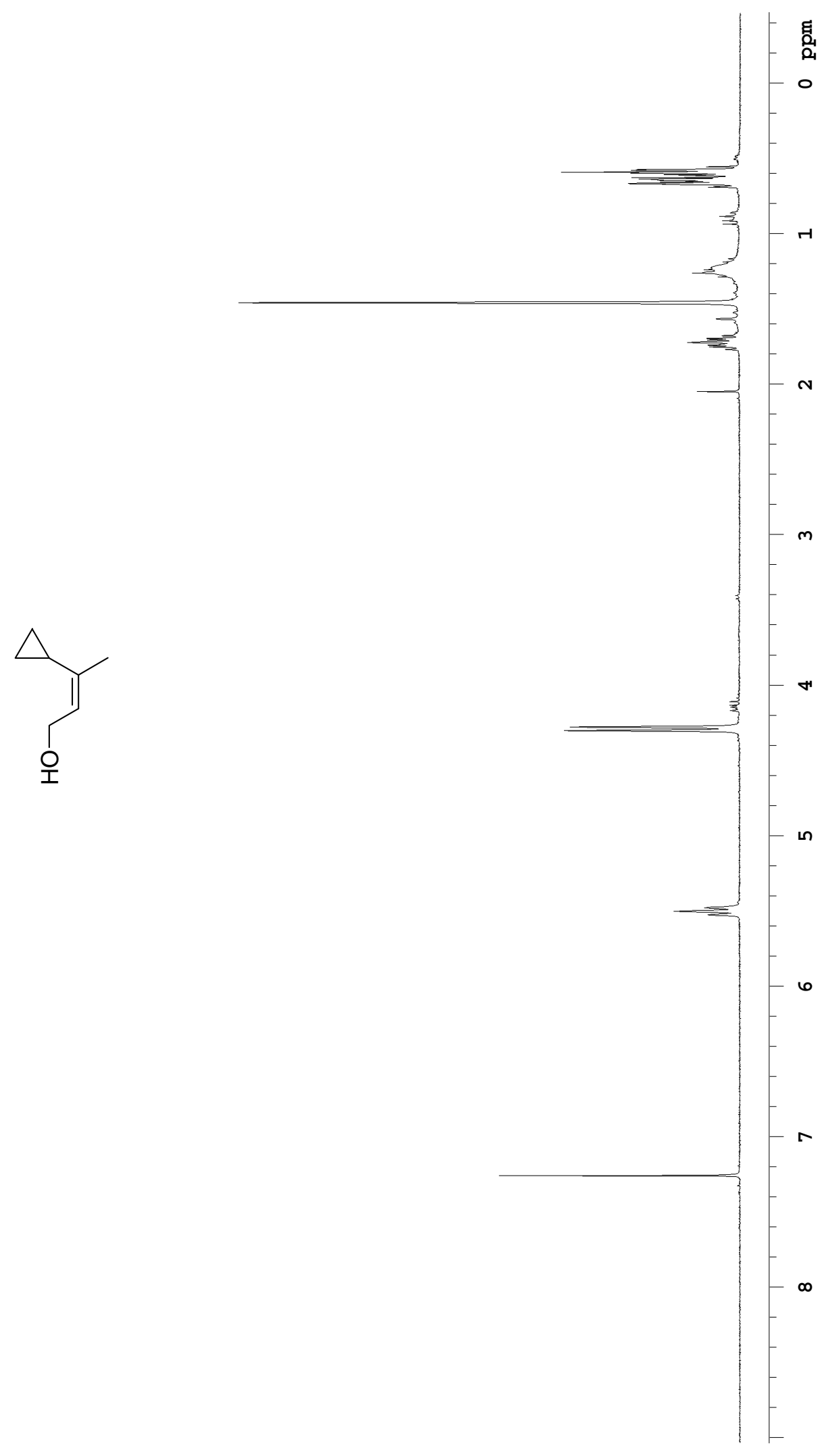




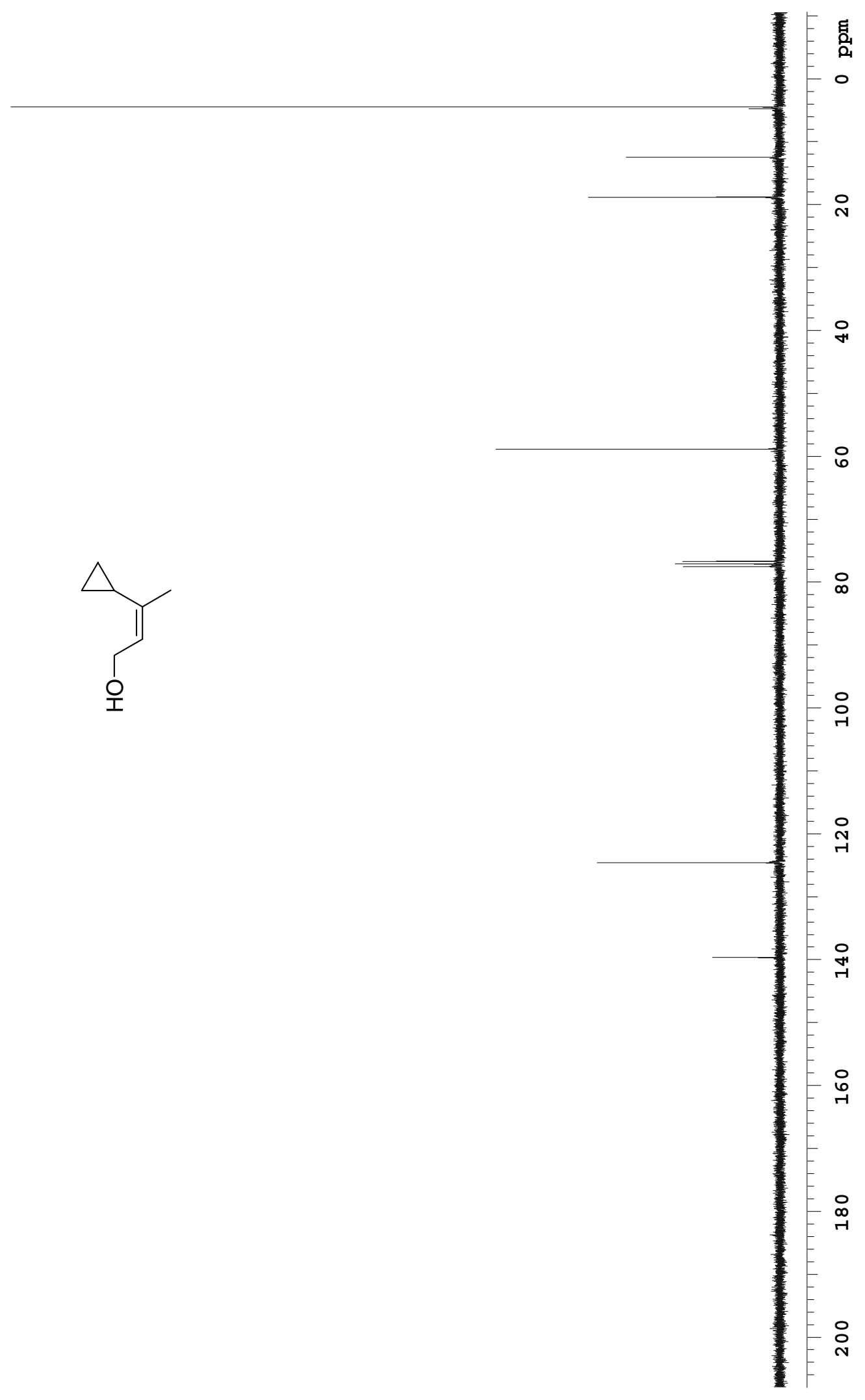




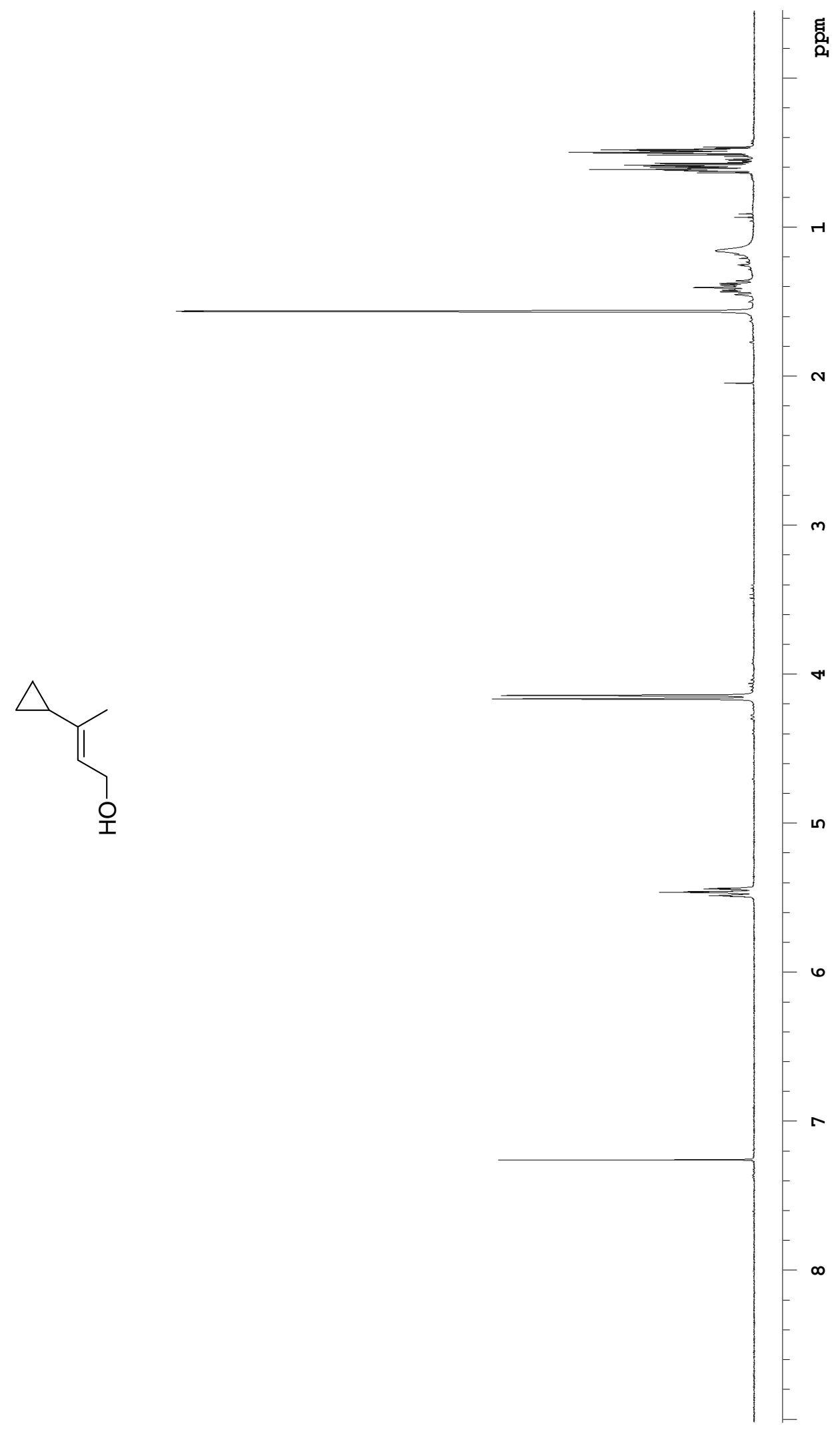




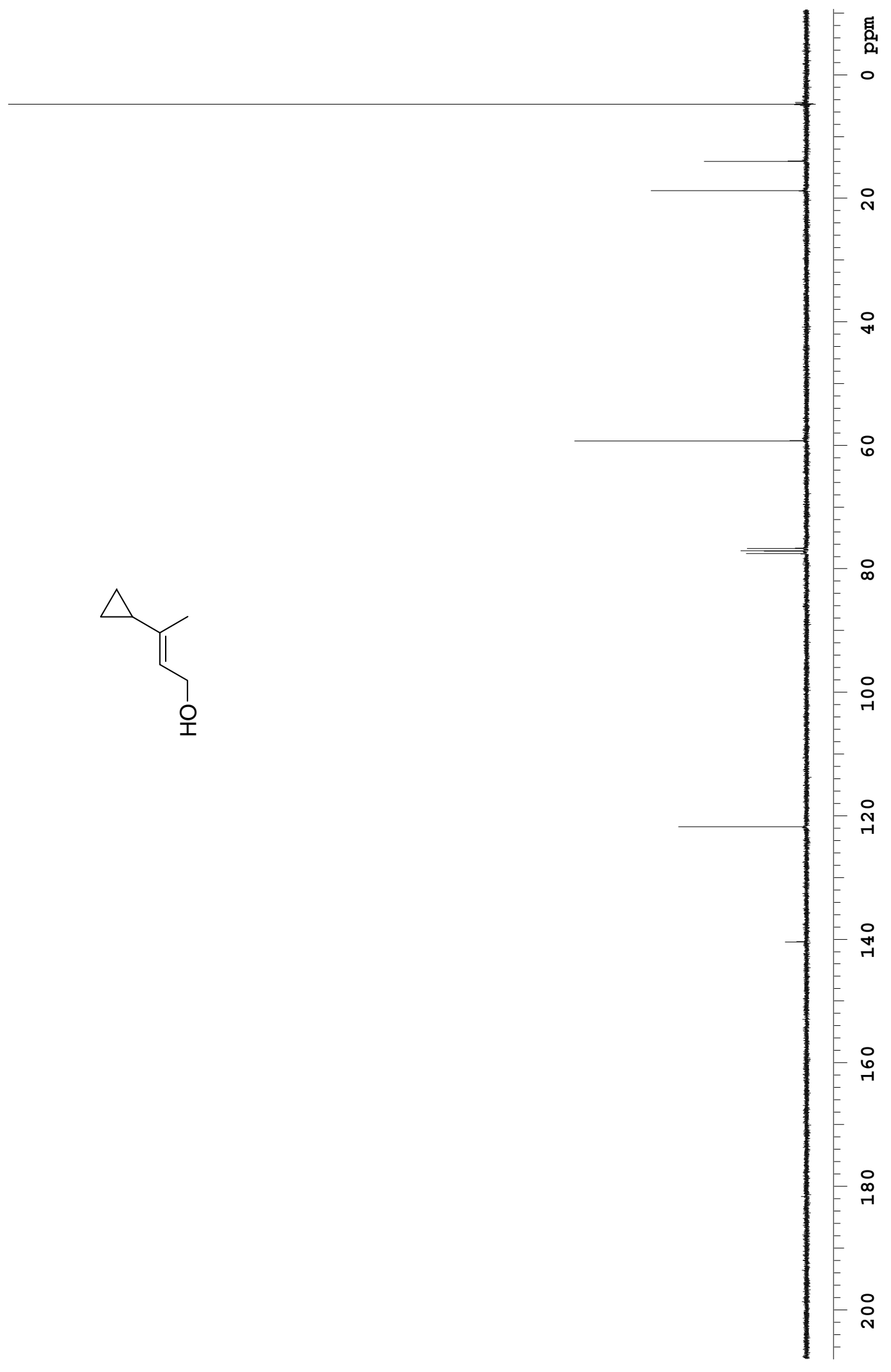




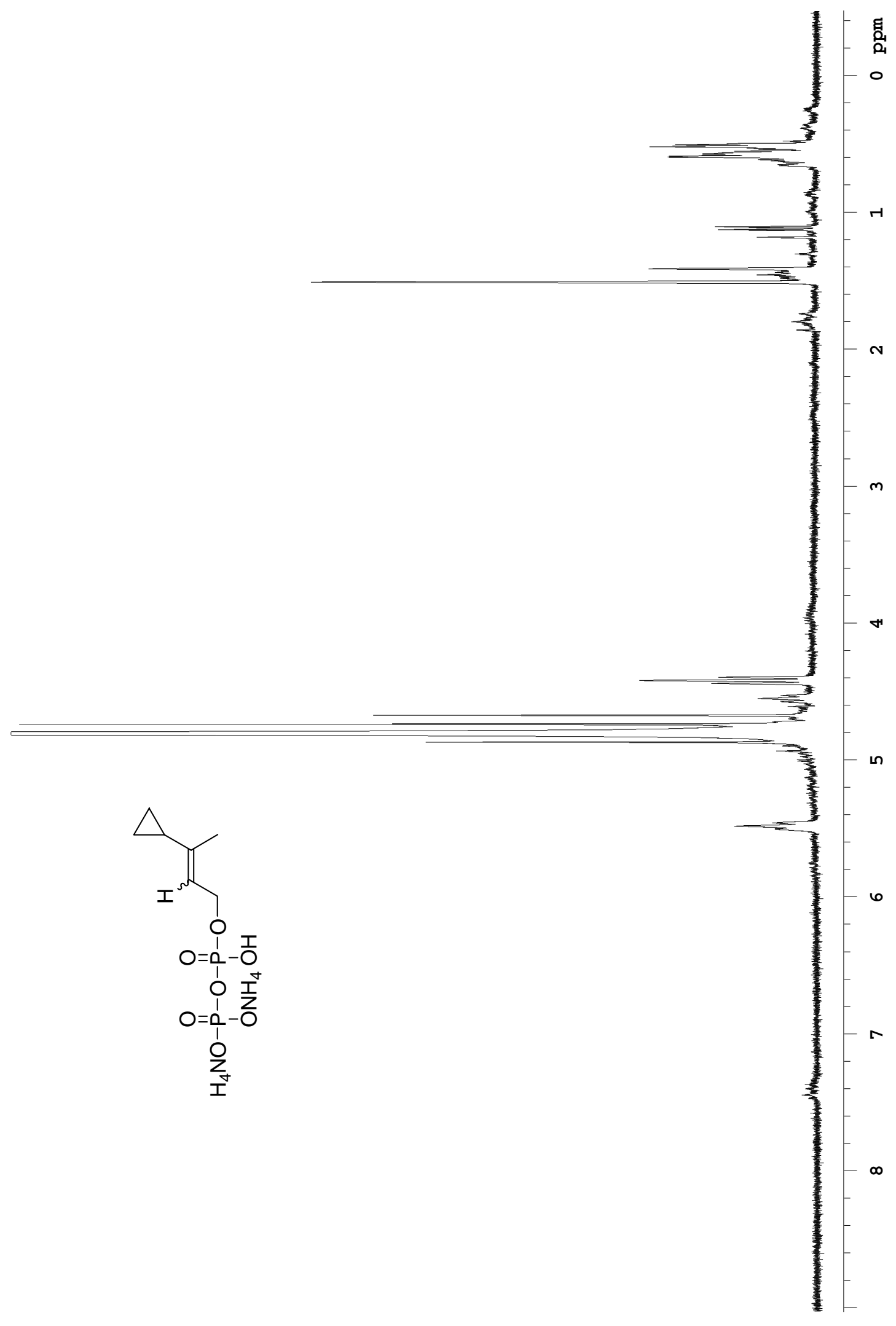




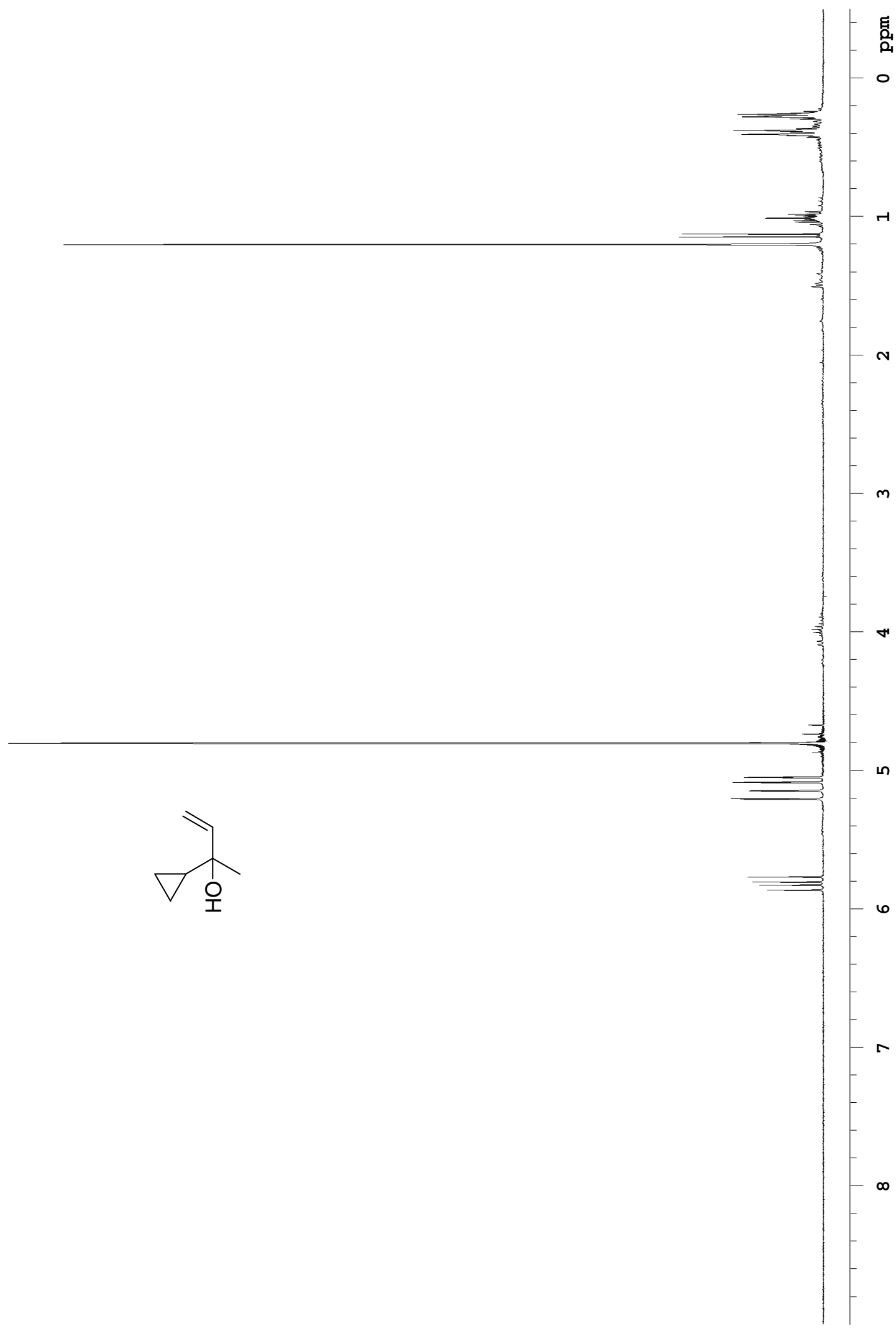




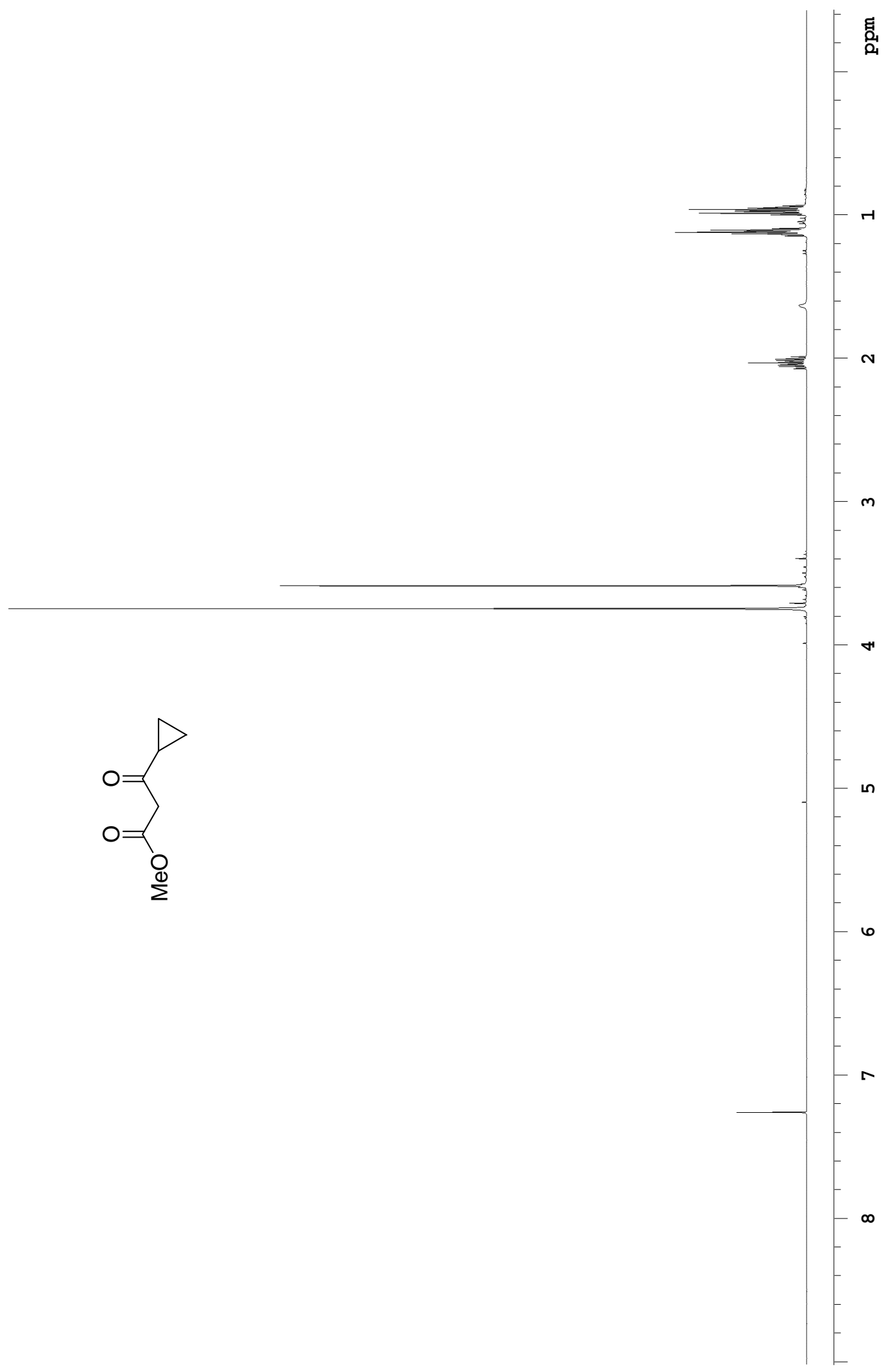




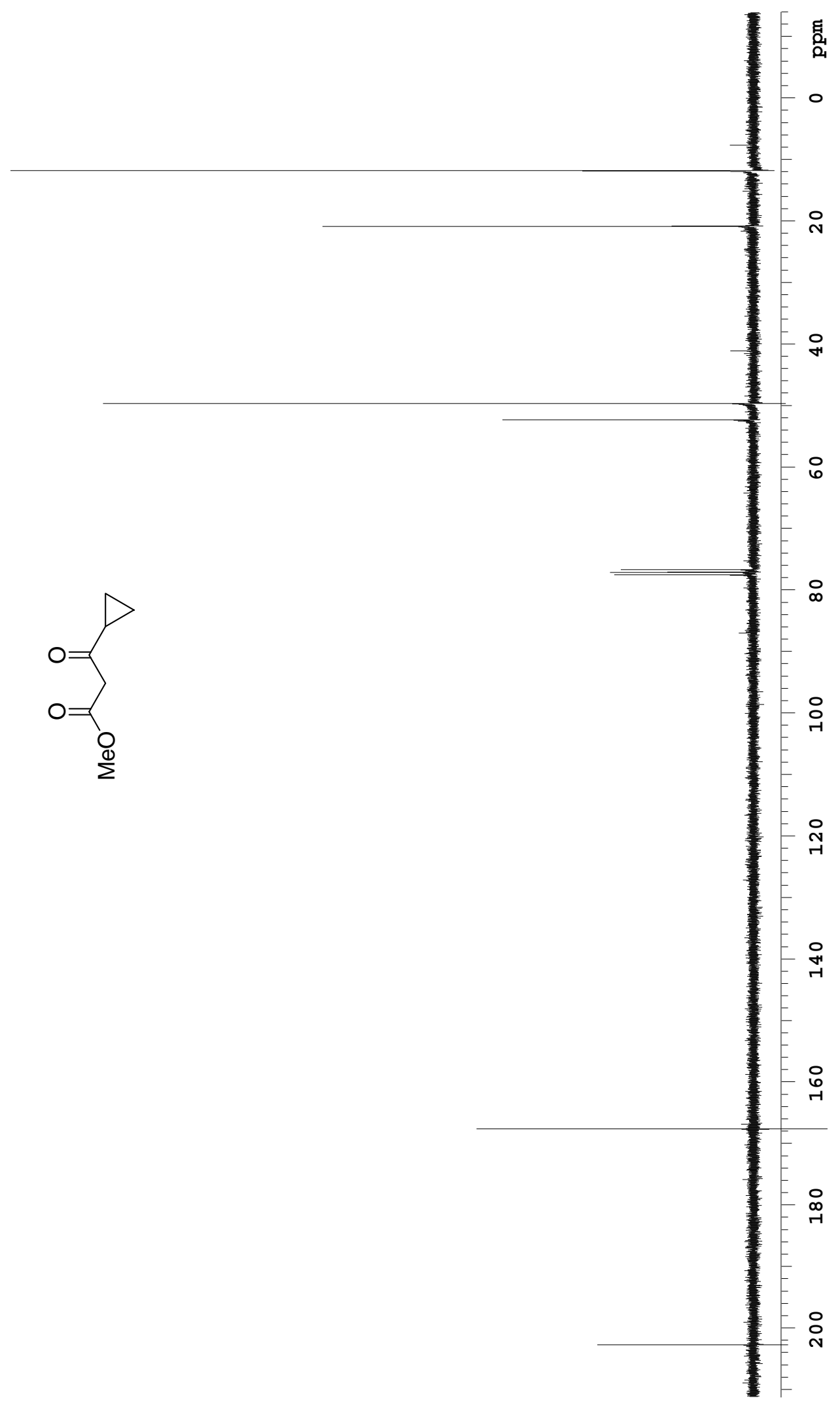




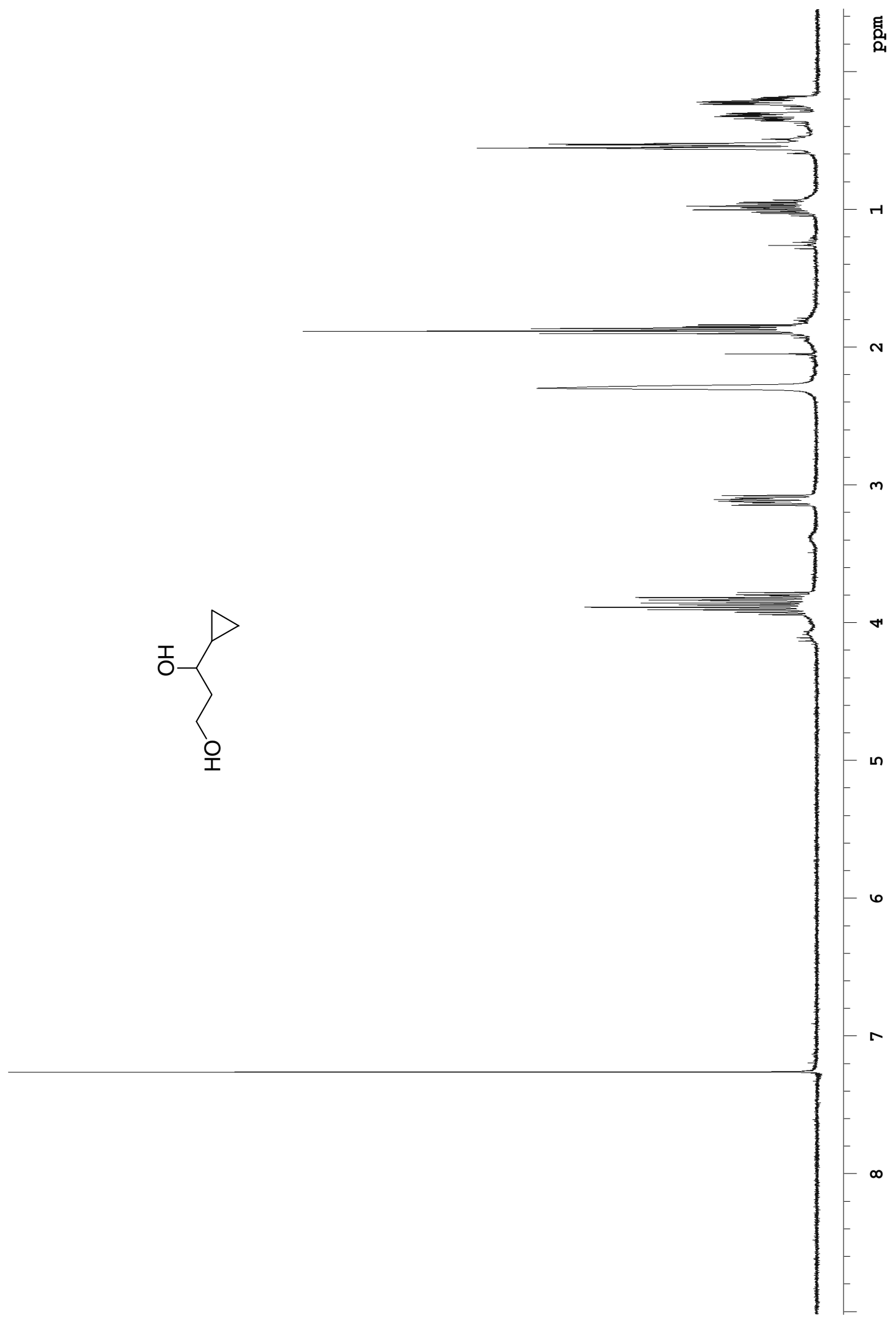




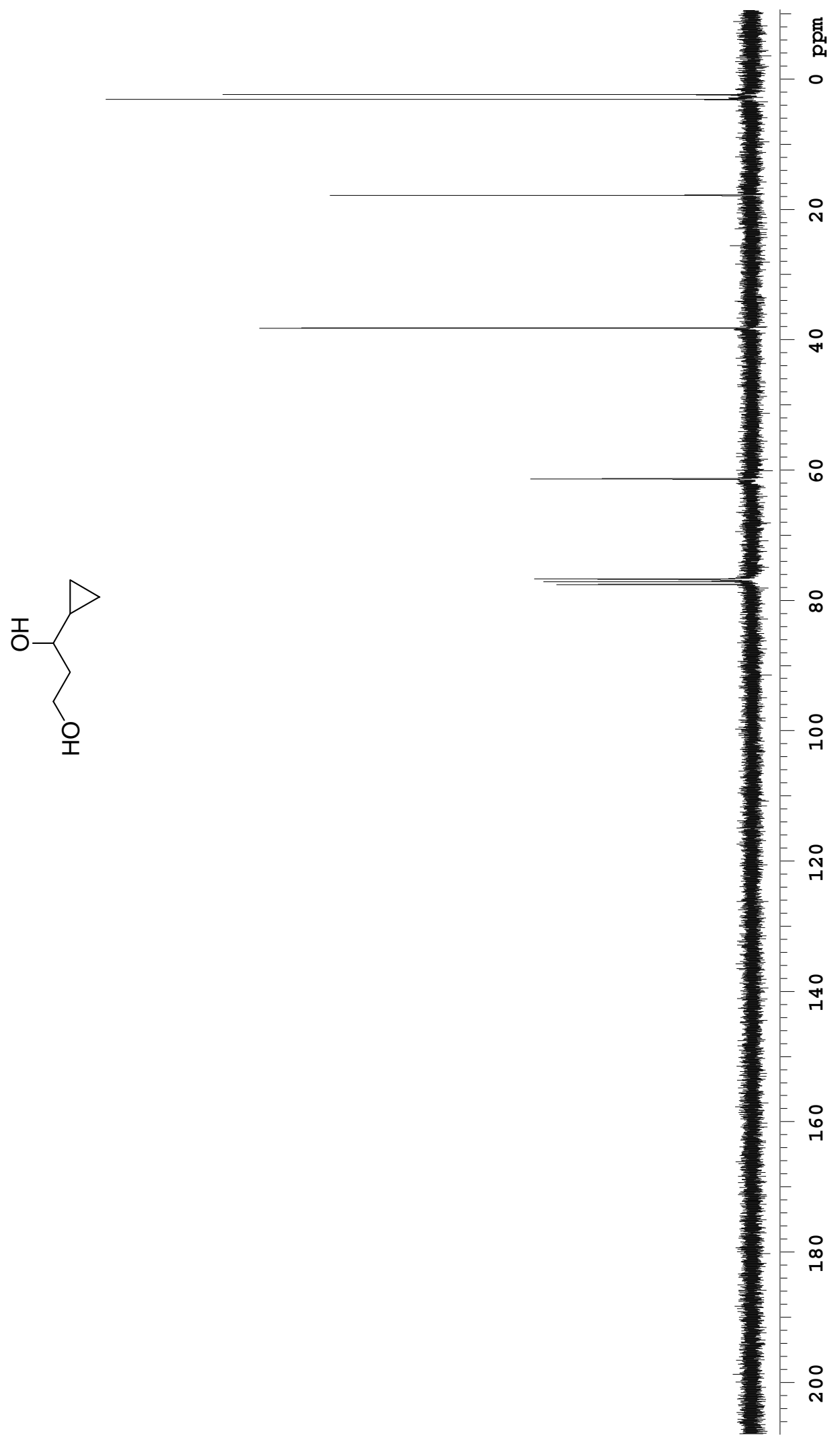




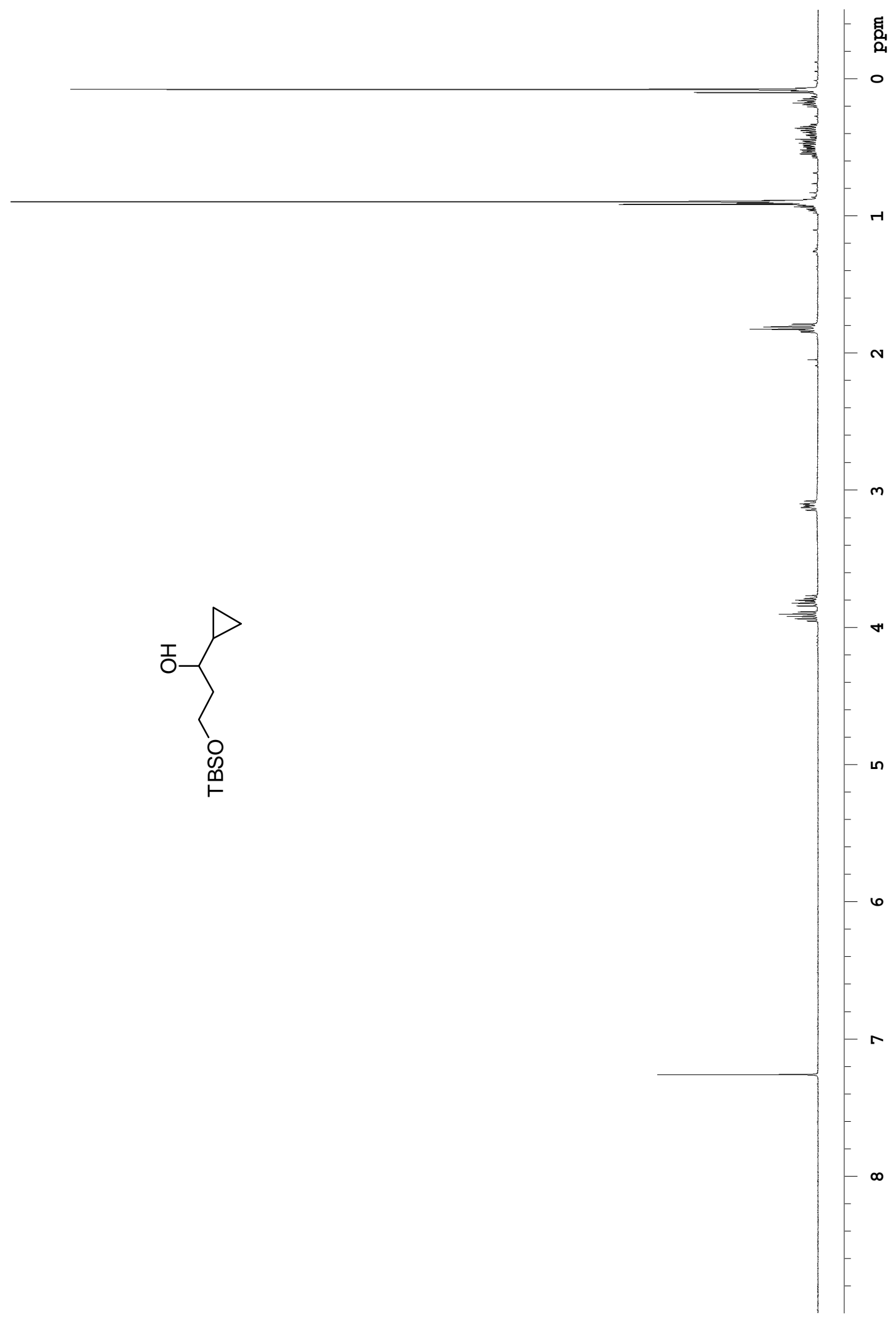




$$
\mid
$$




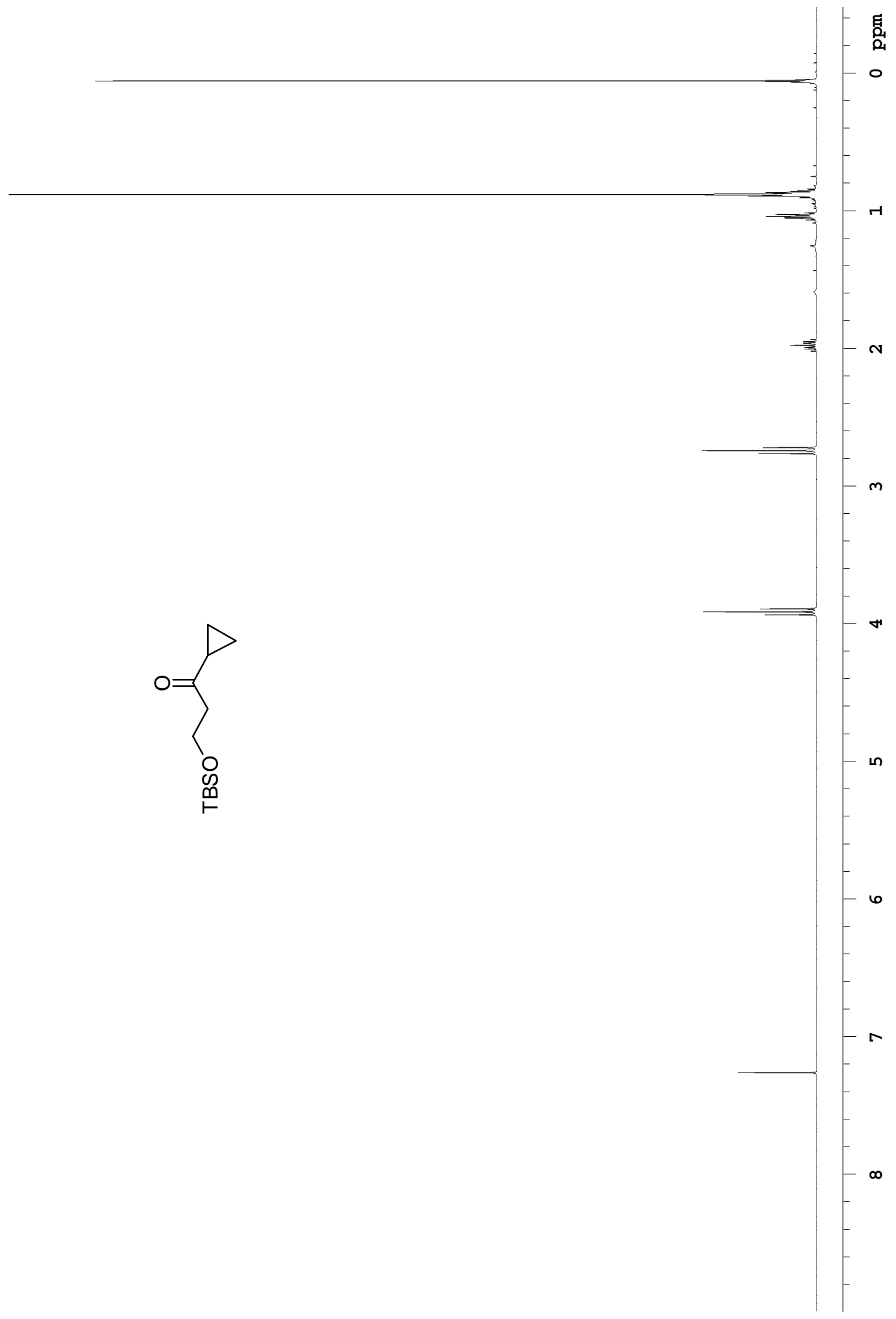




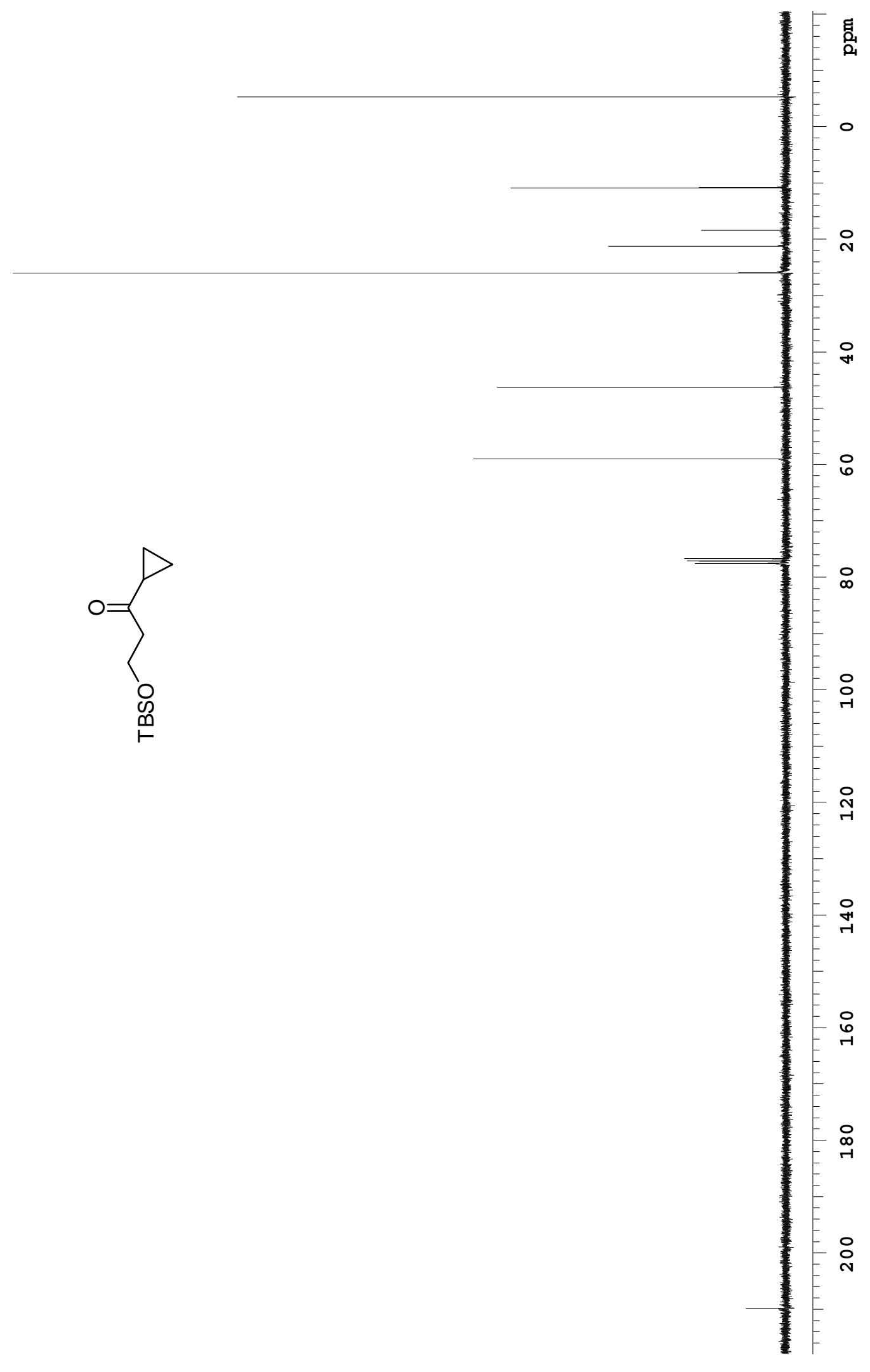




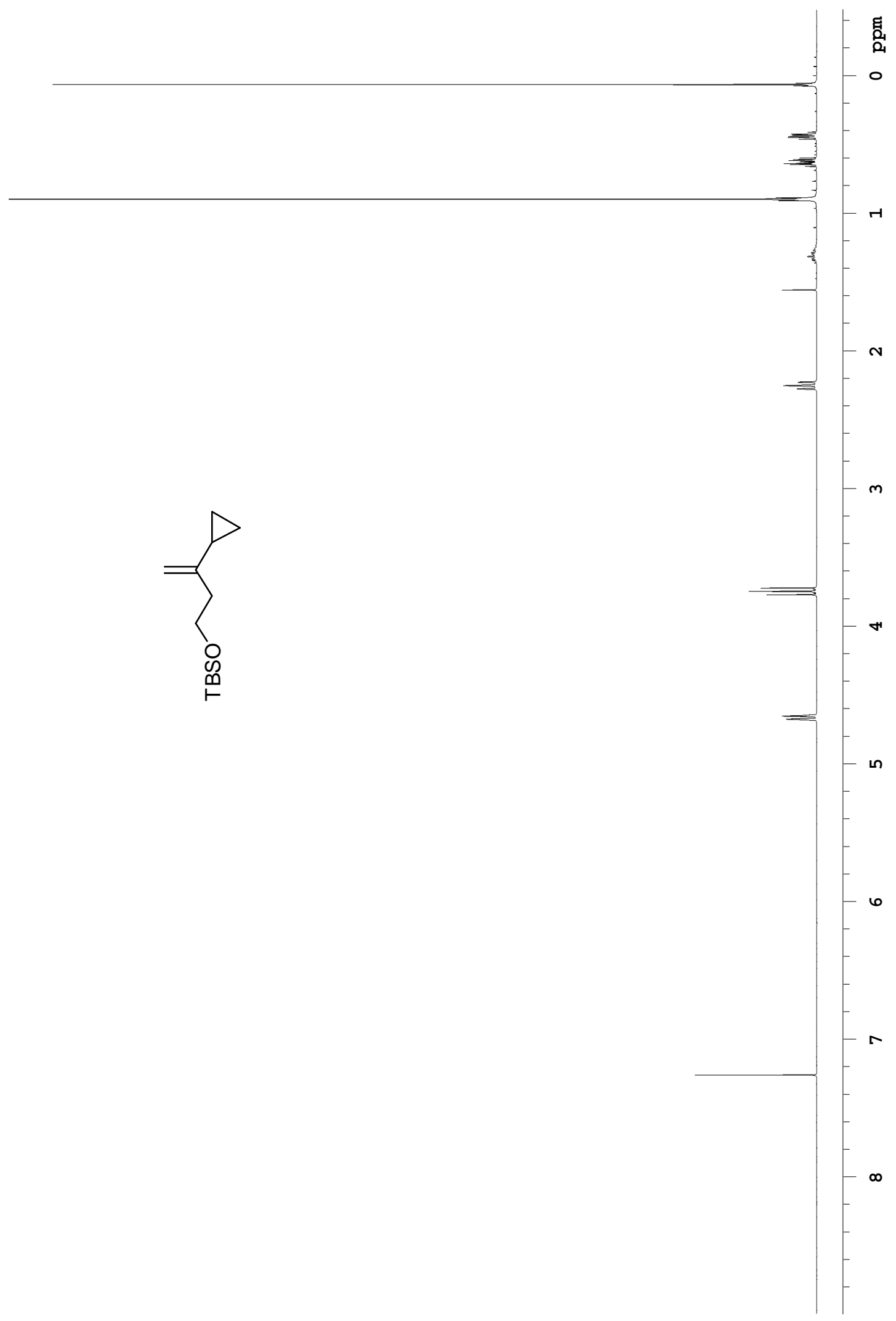




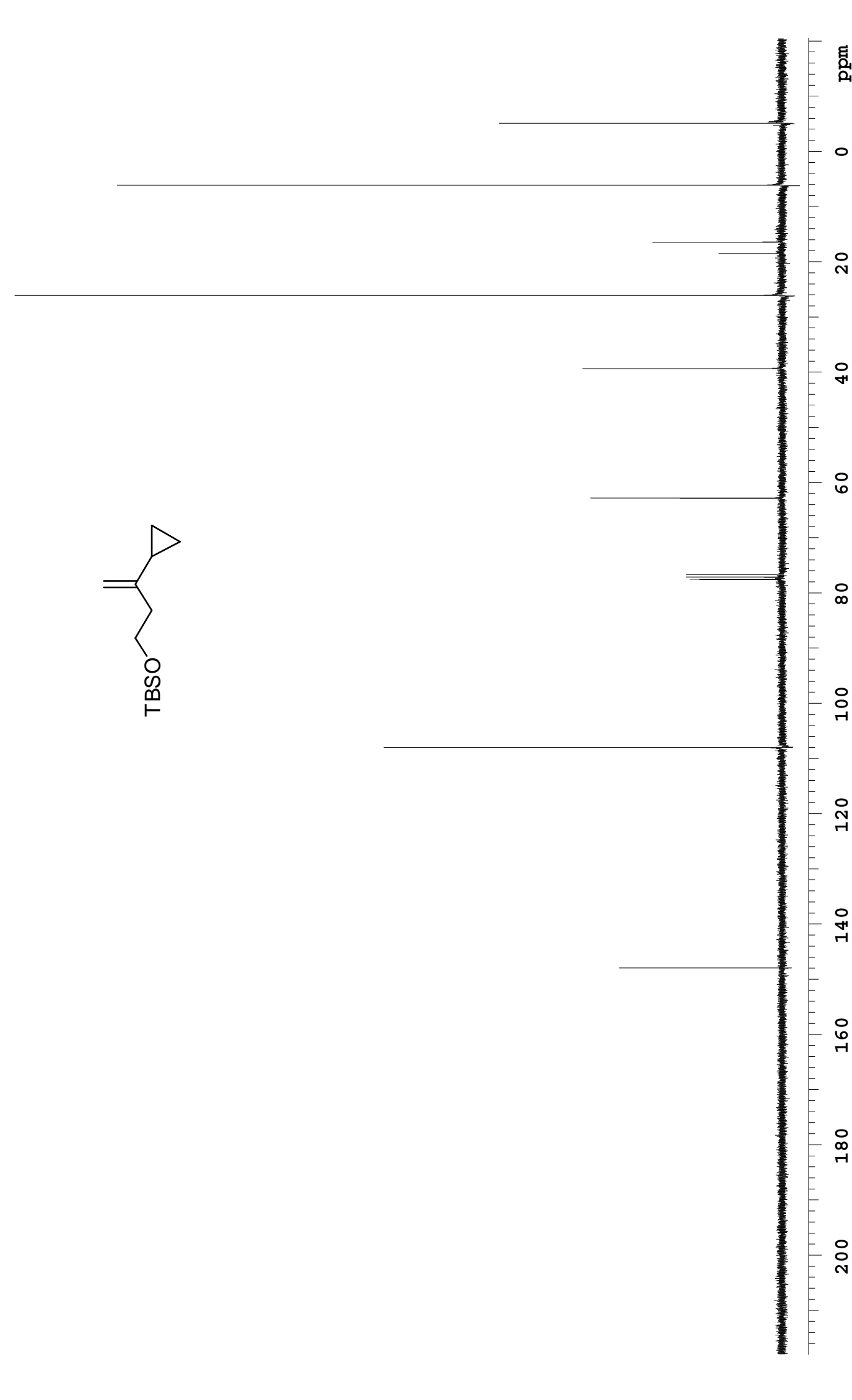




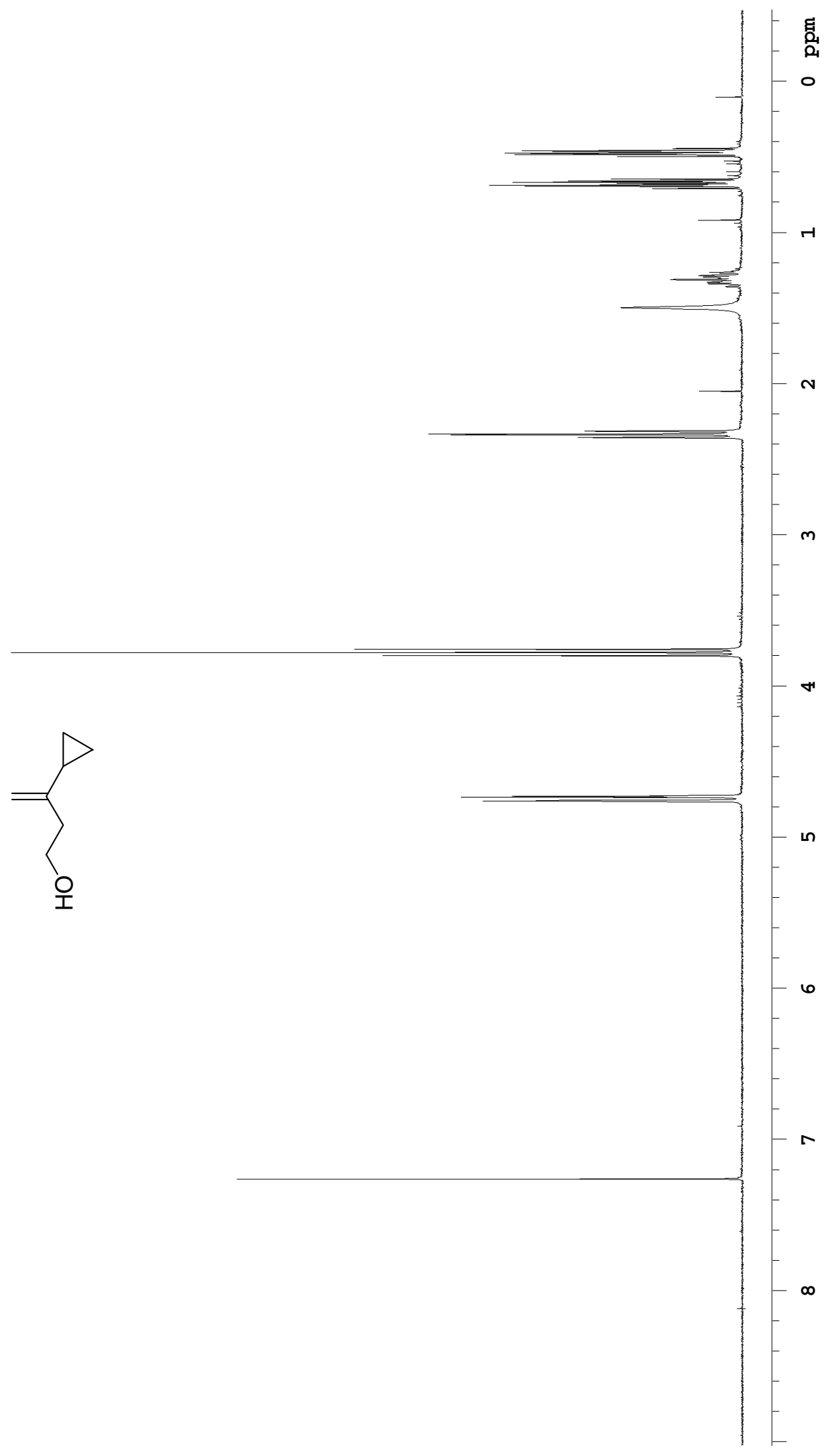




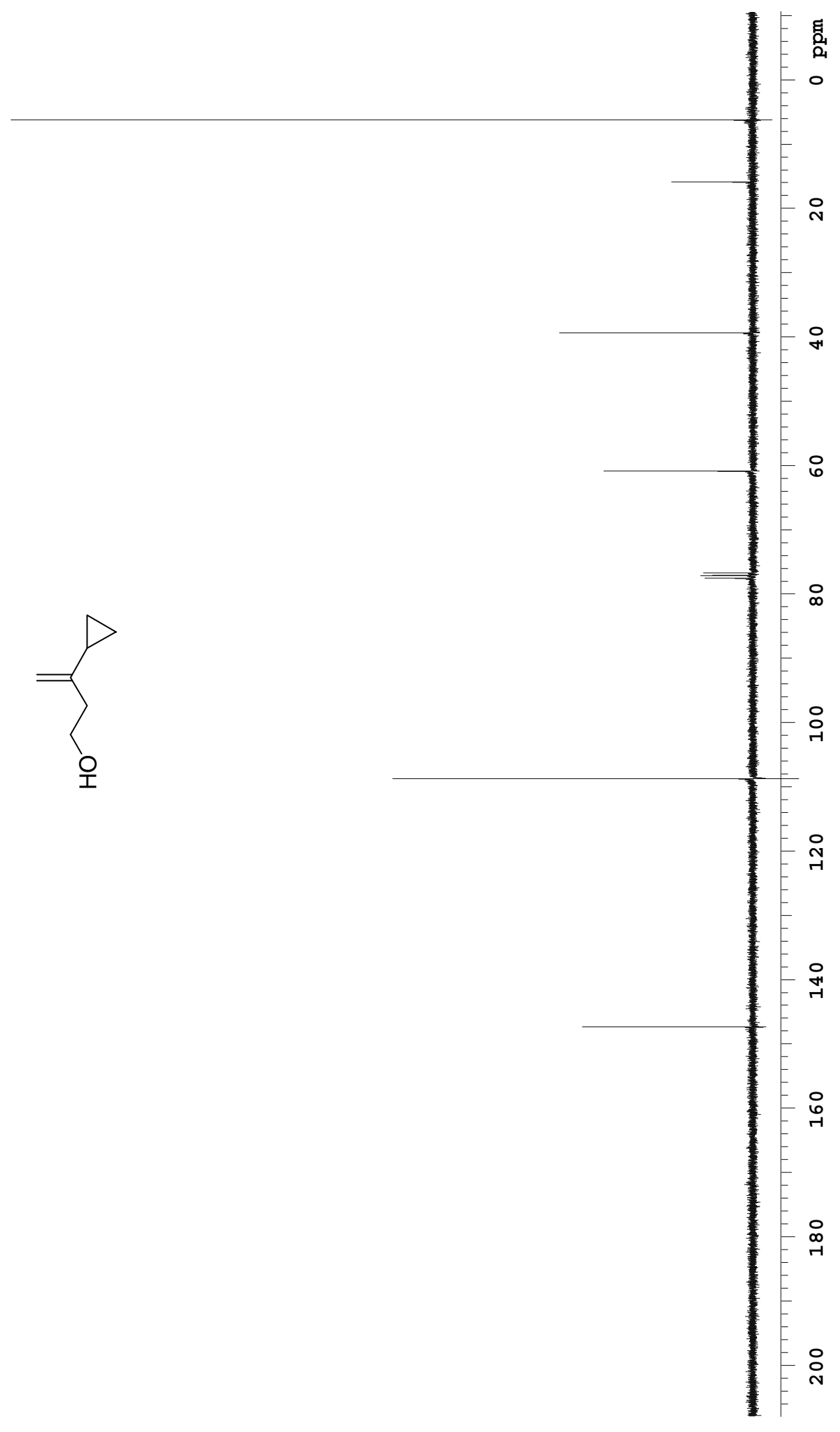




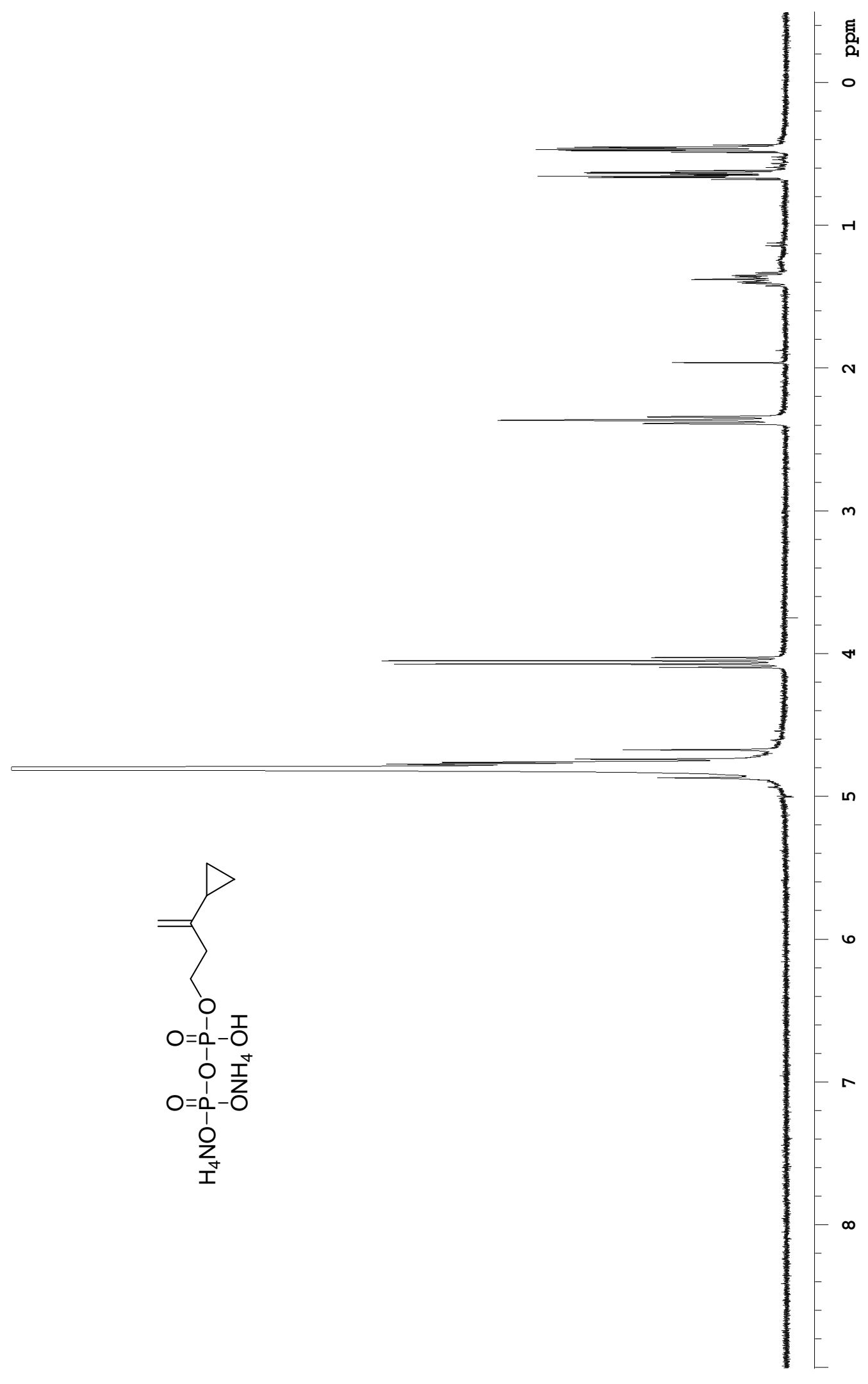



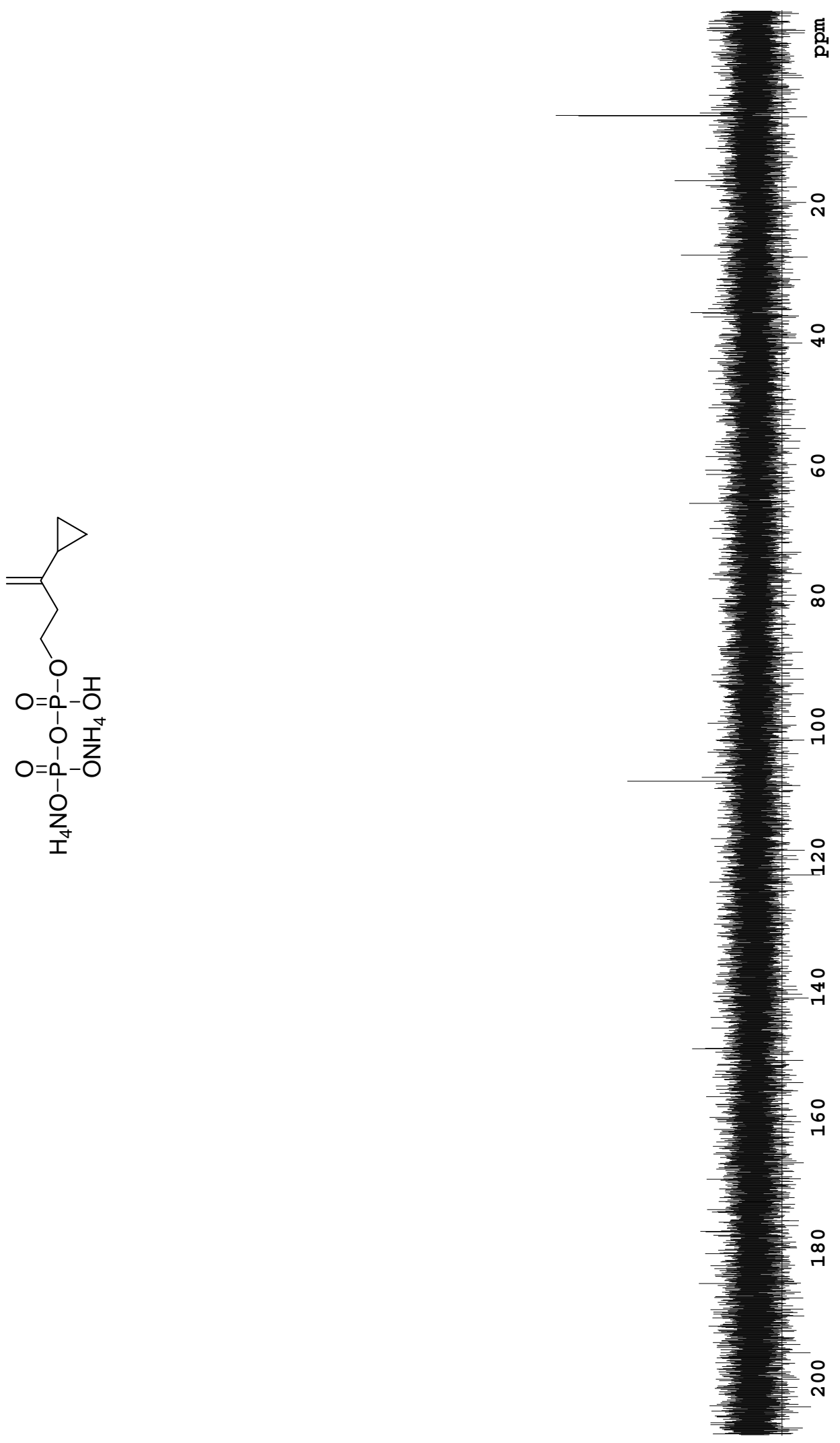


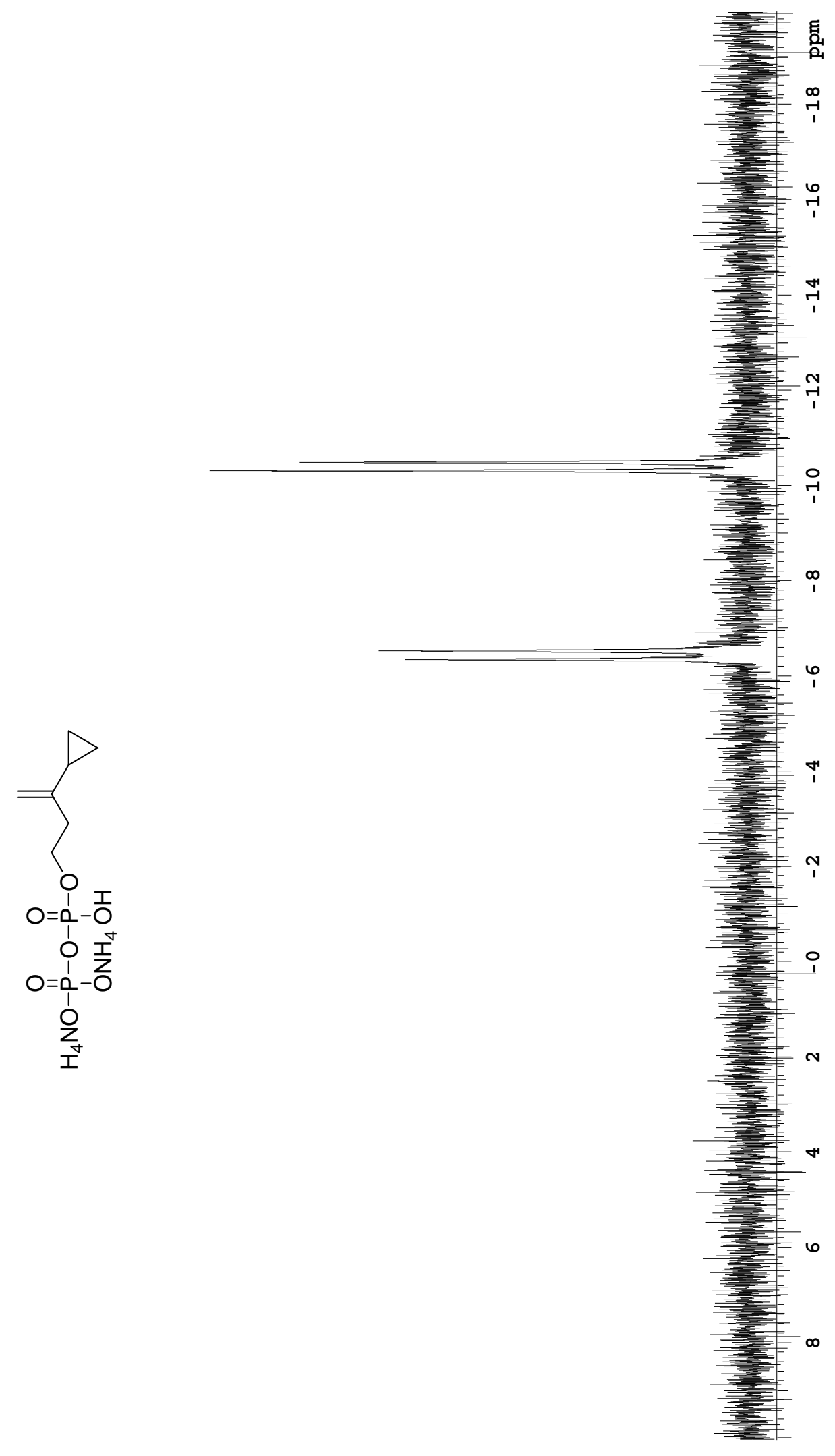




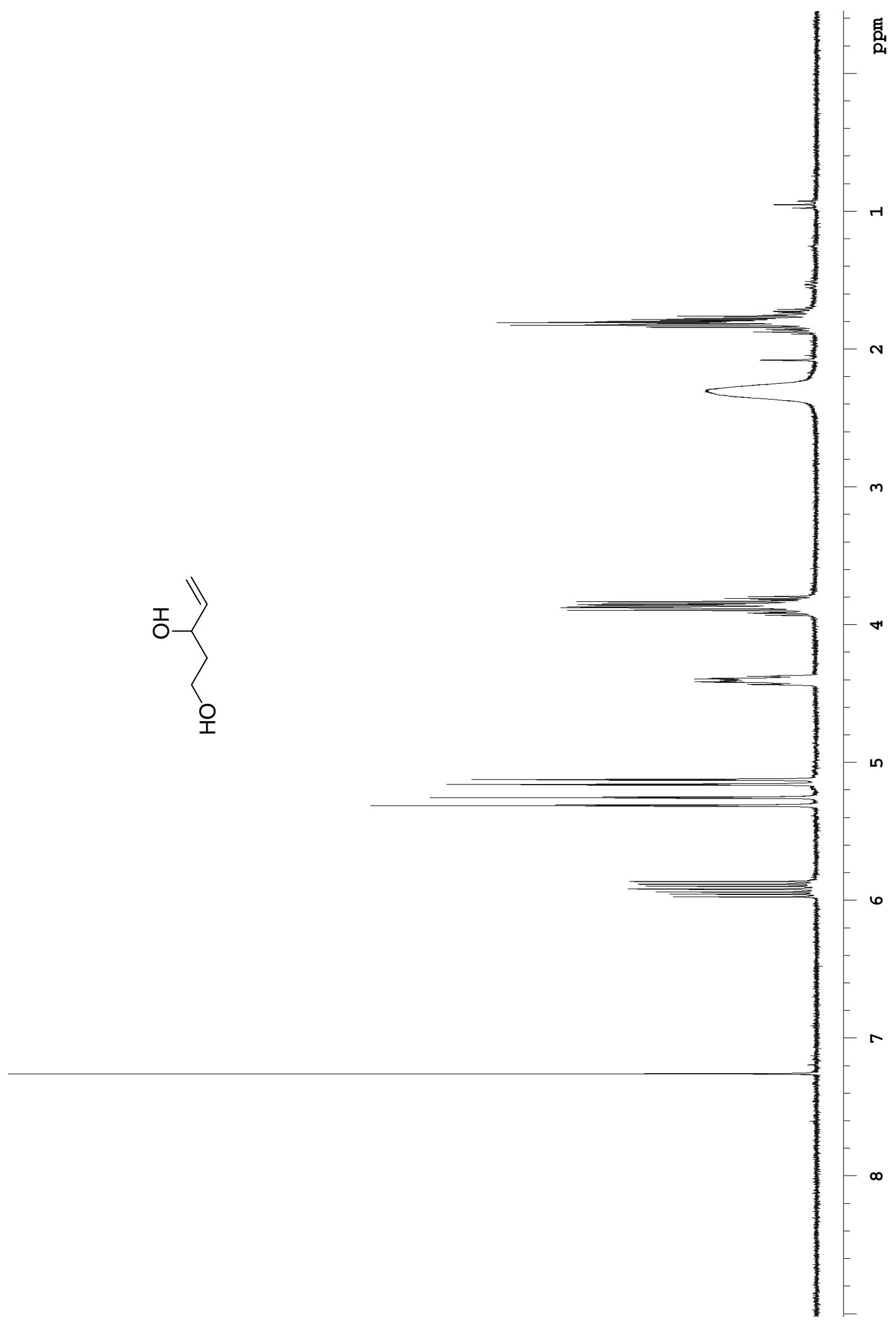




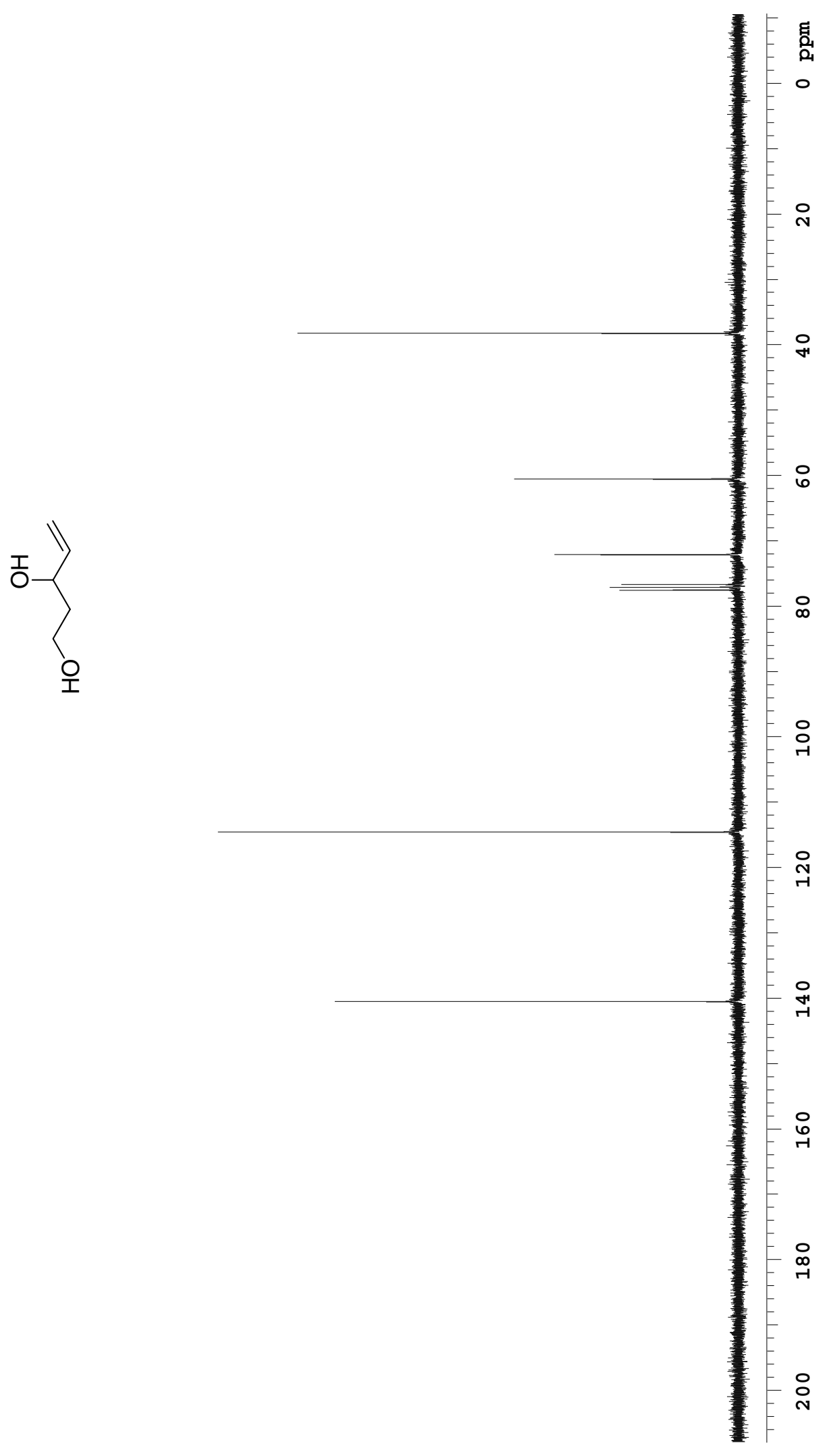




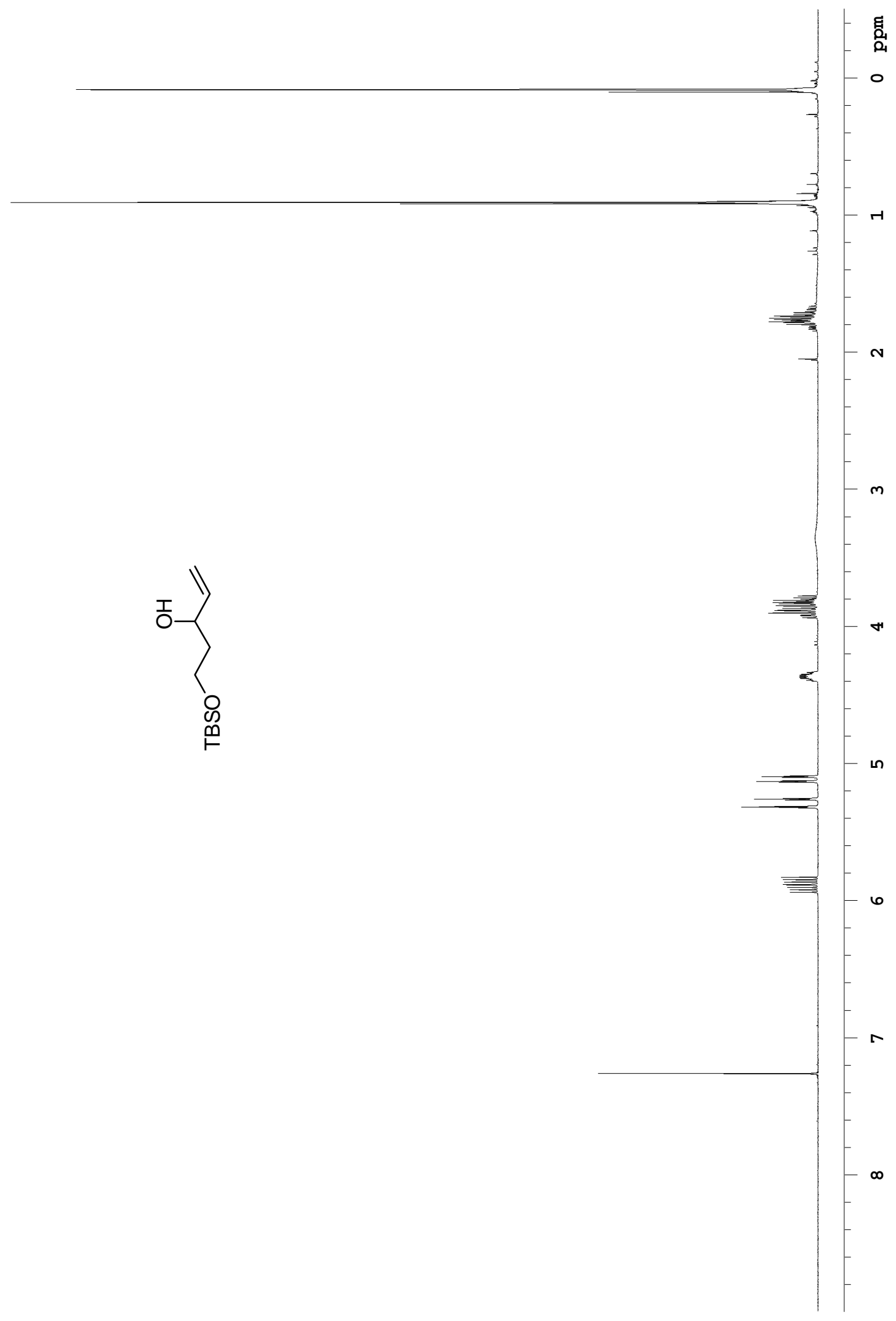




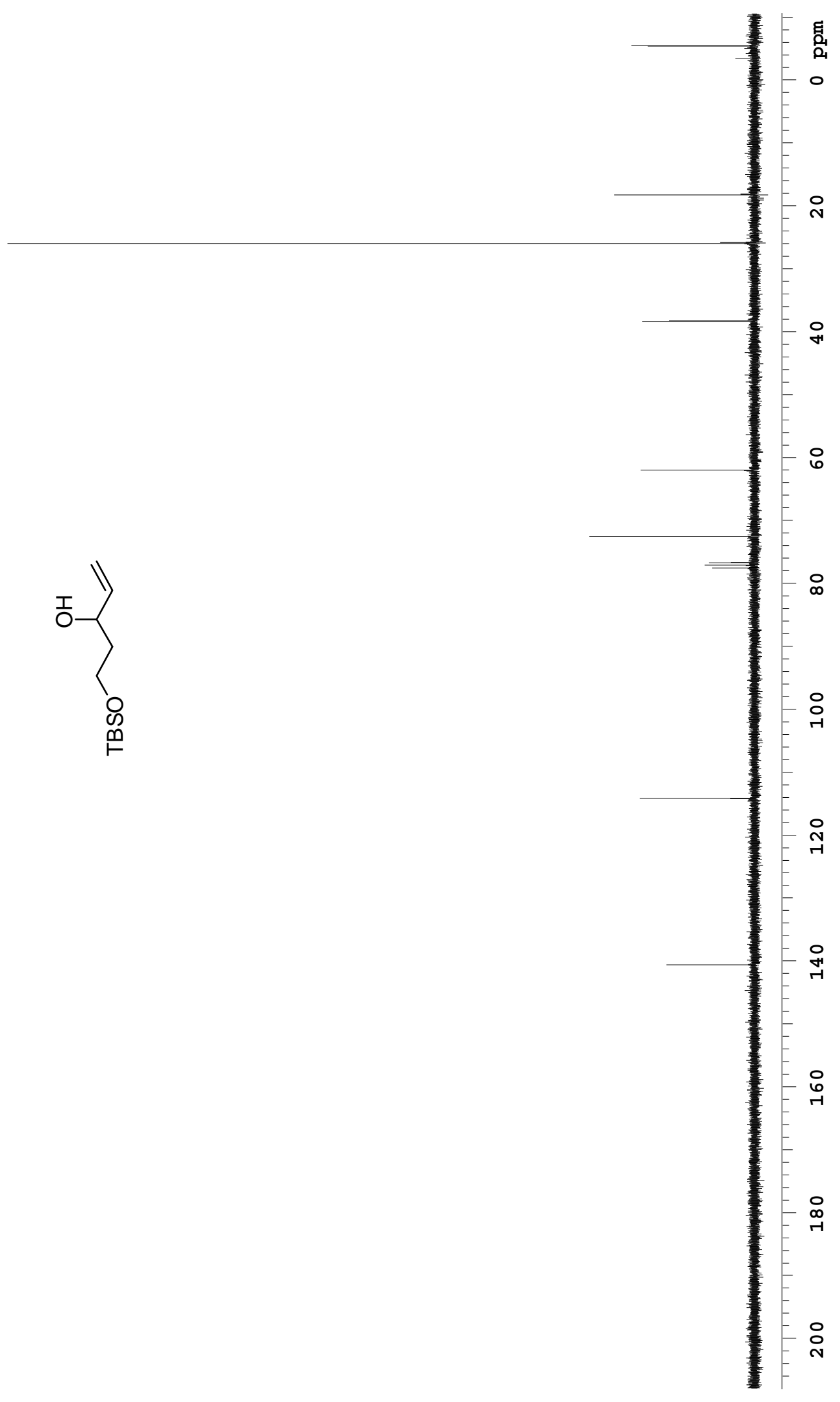




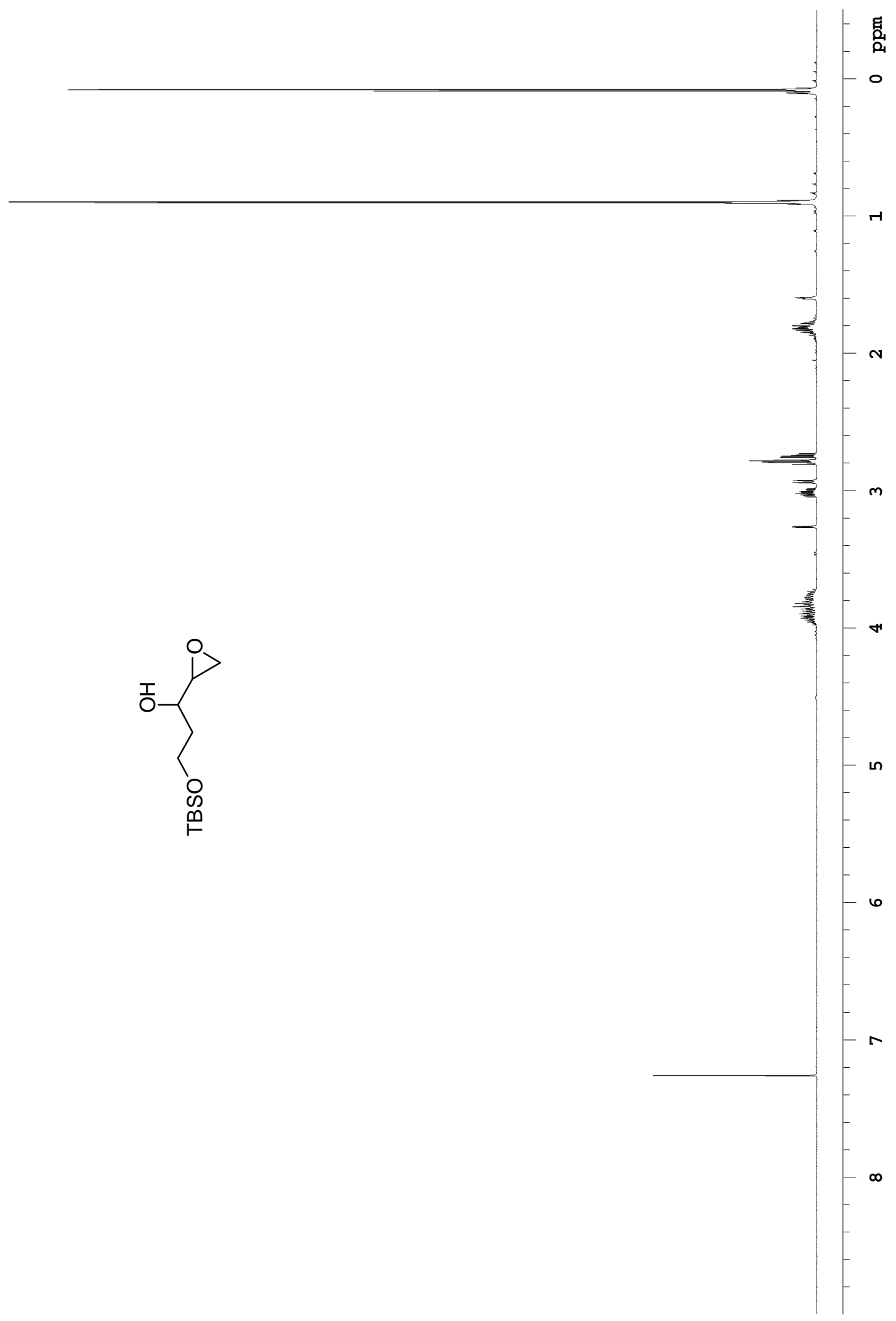




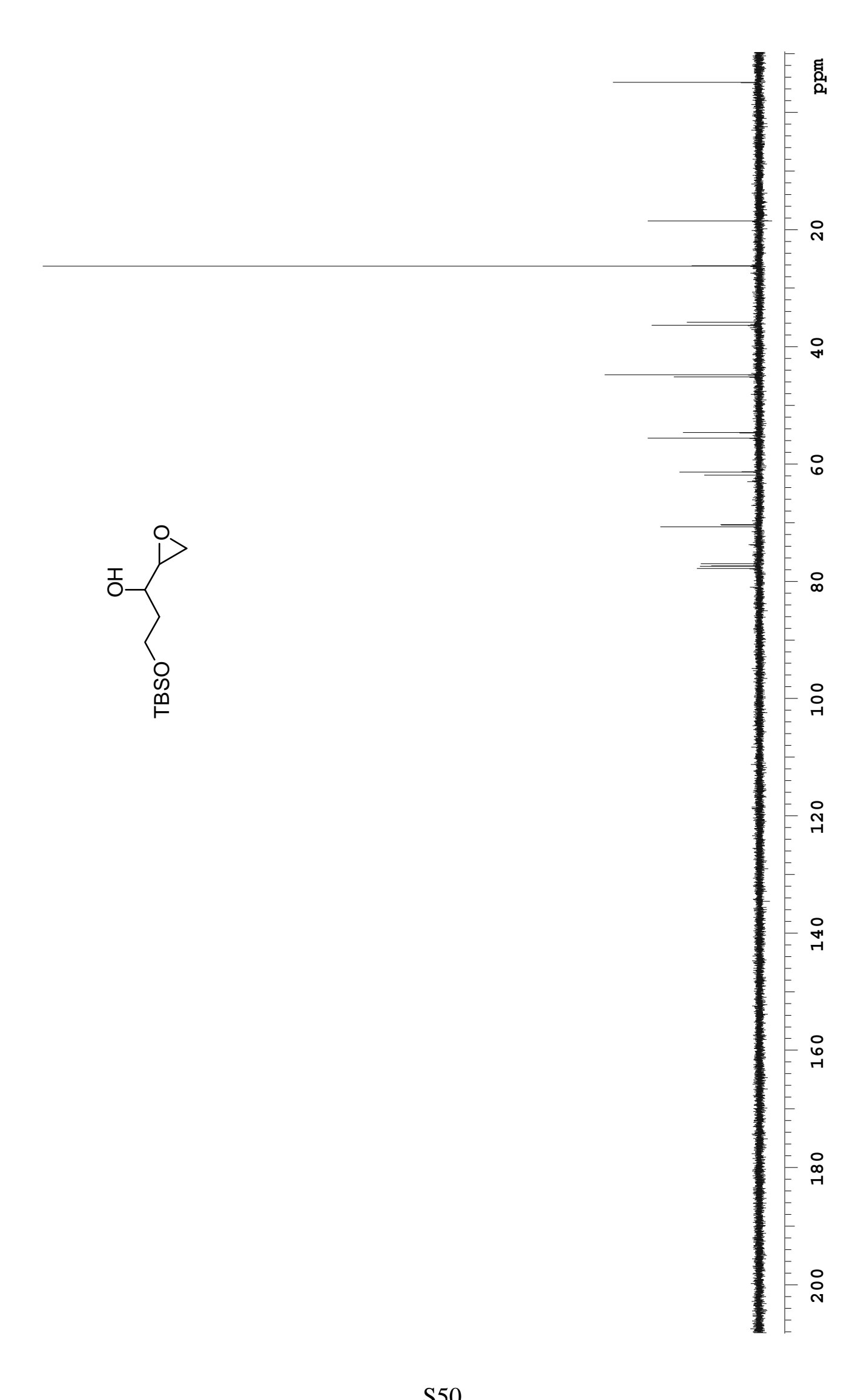




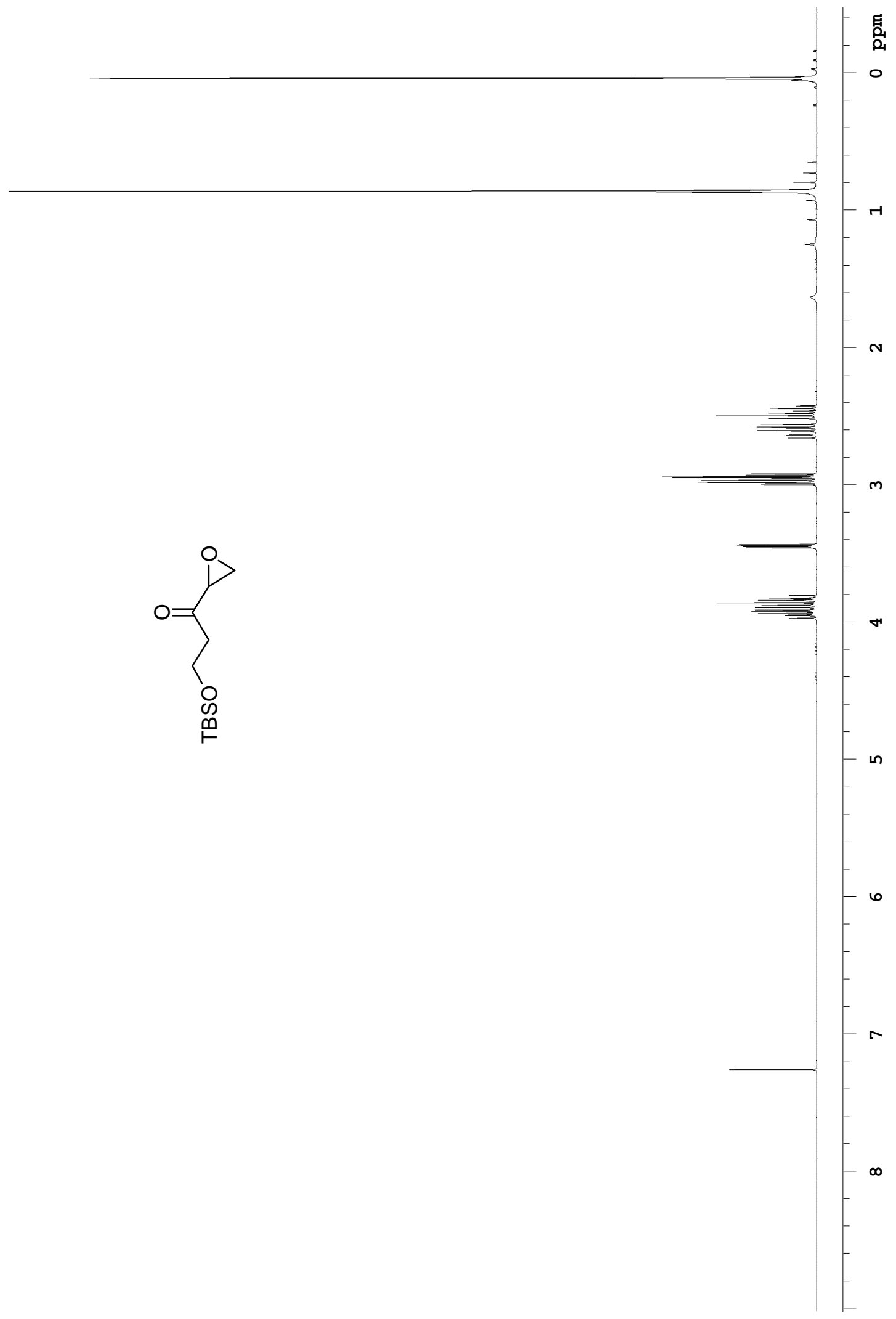




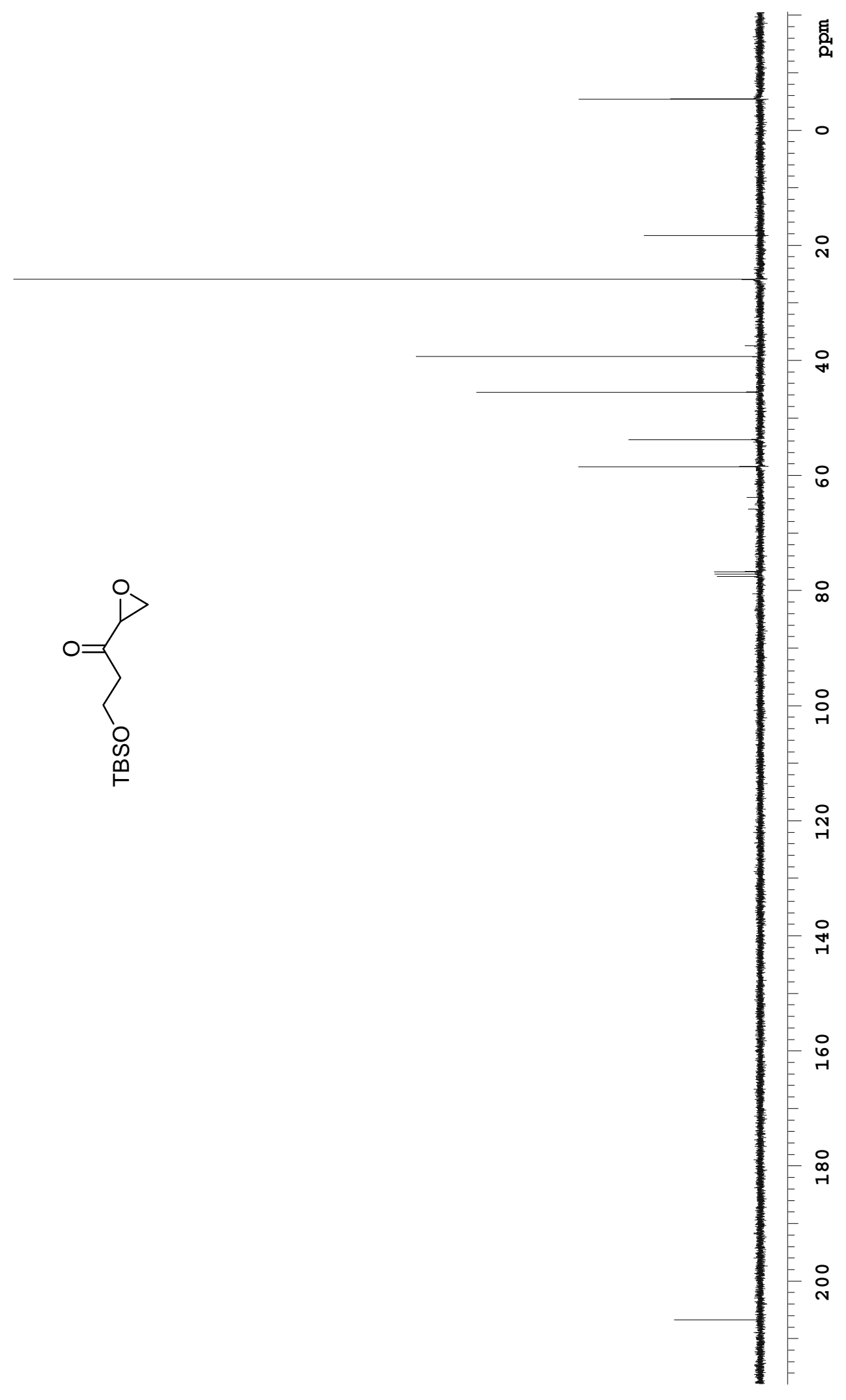




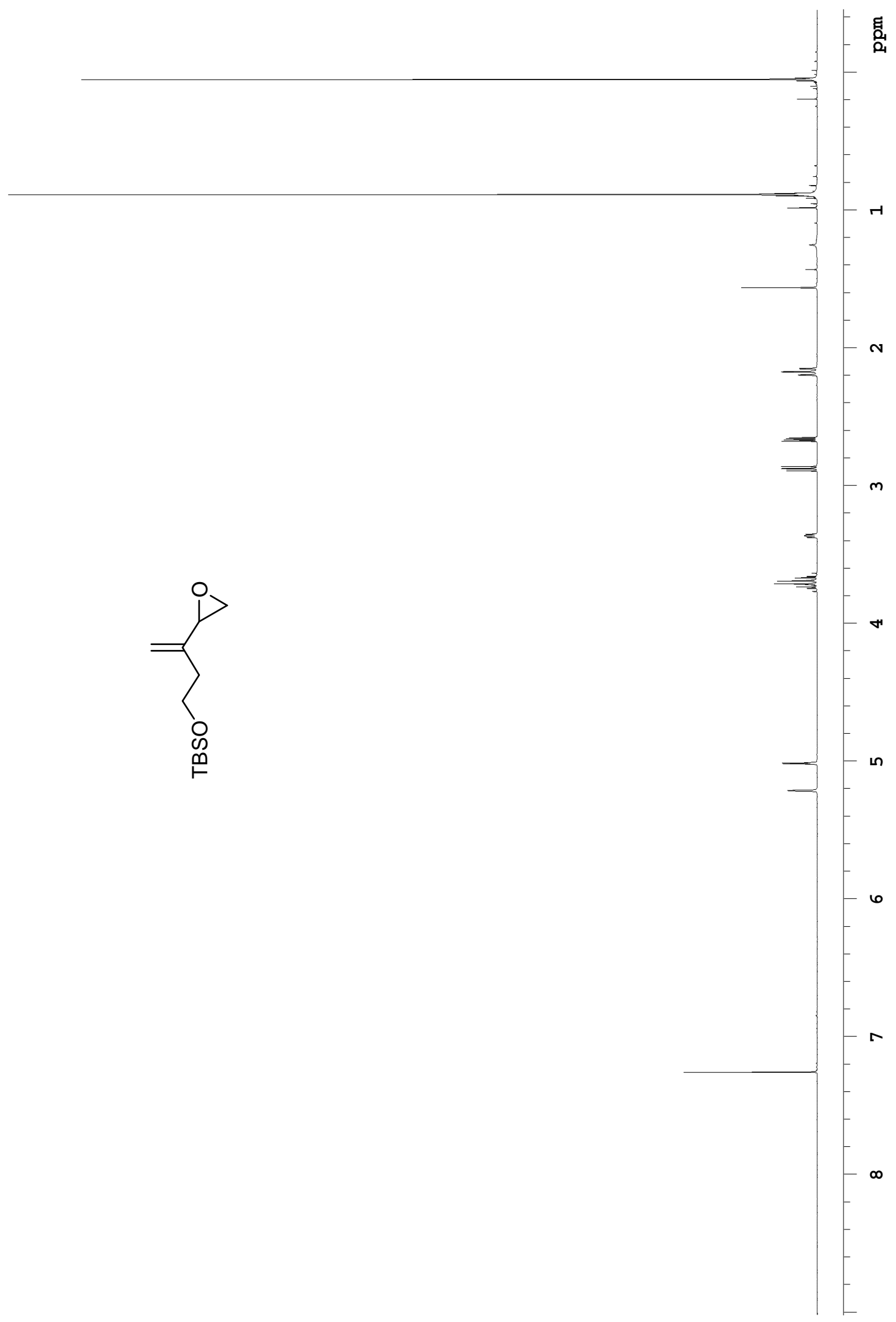




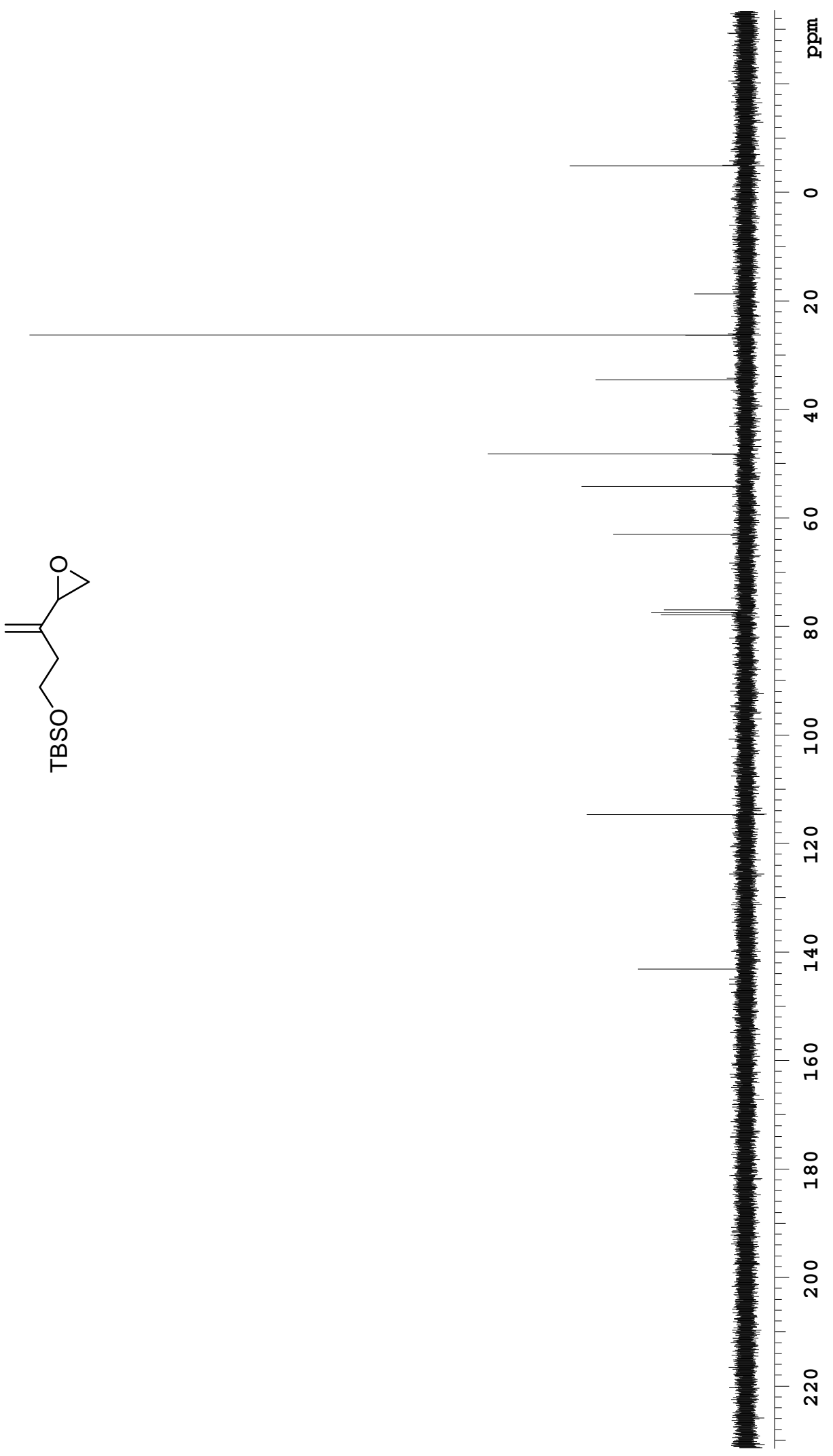




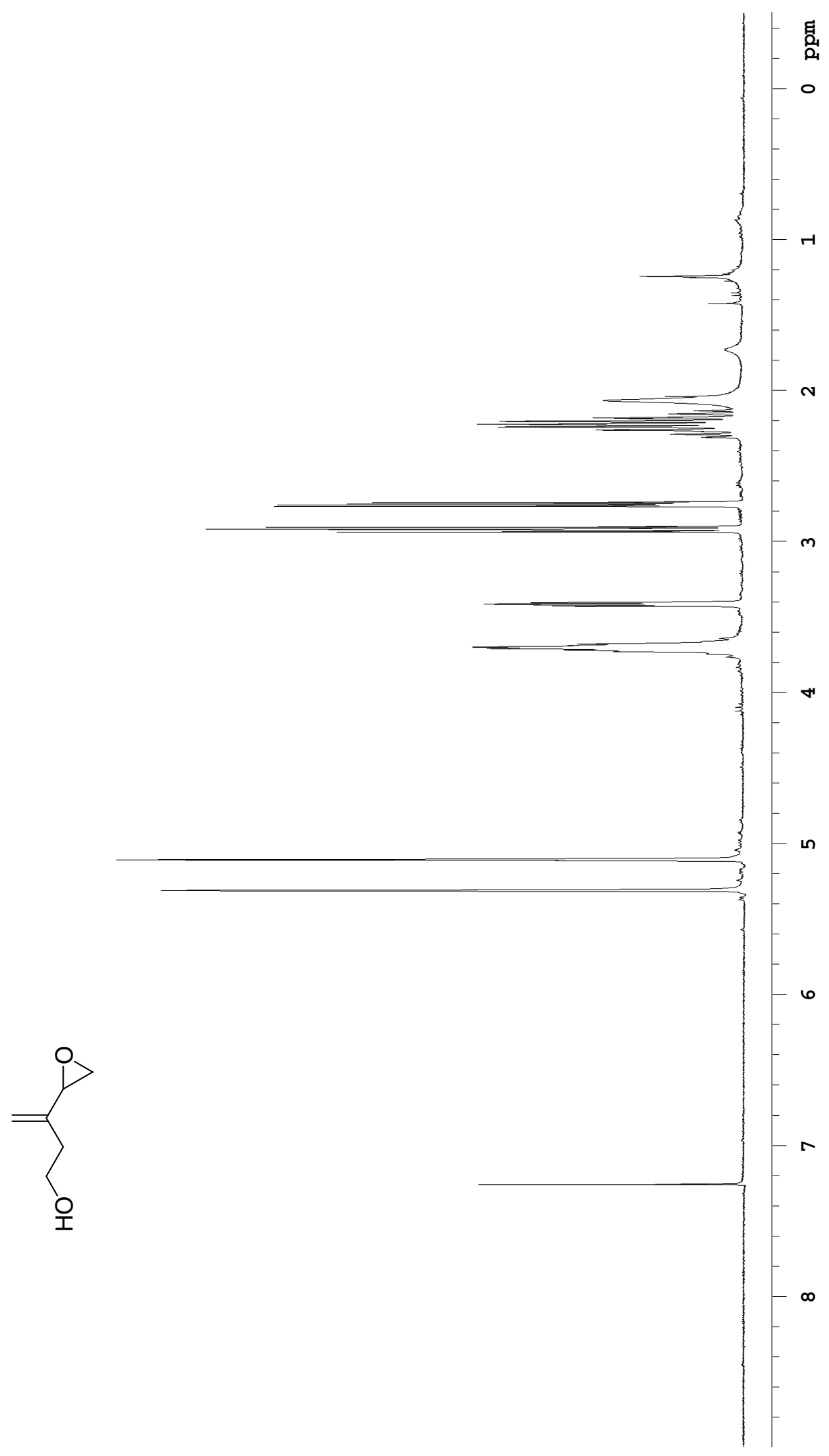




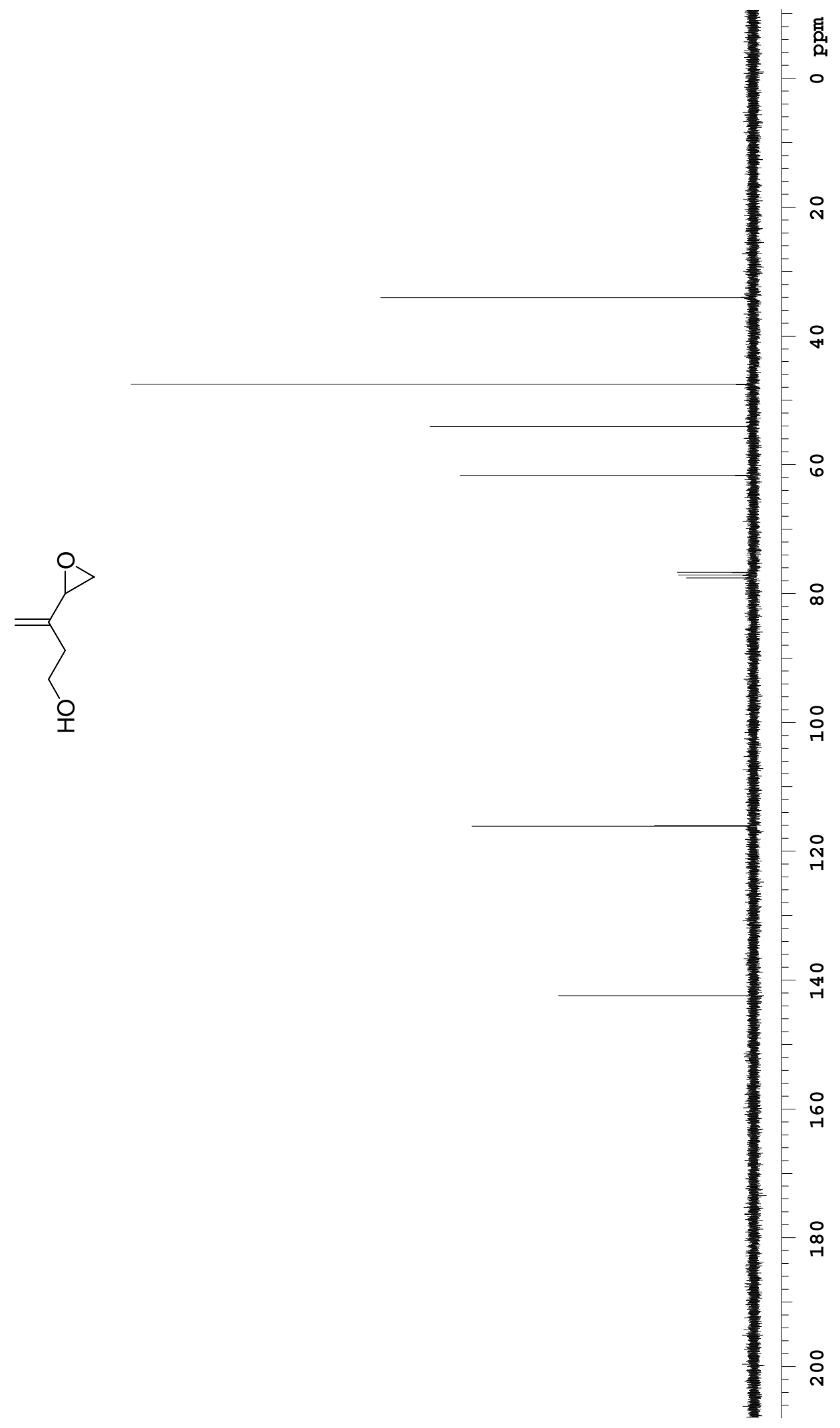




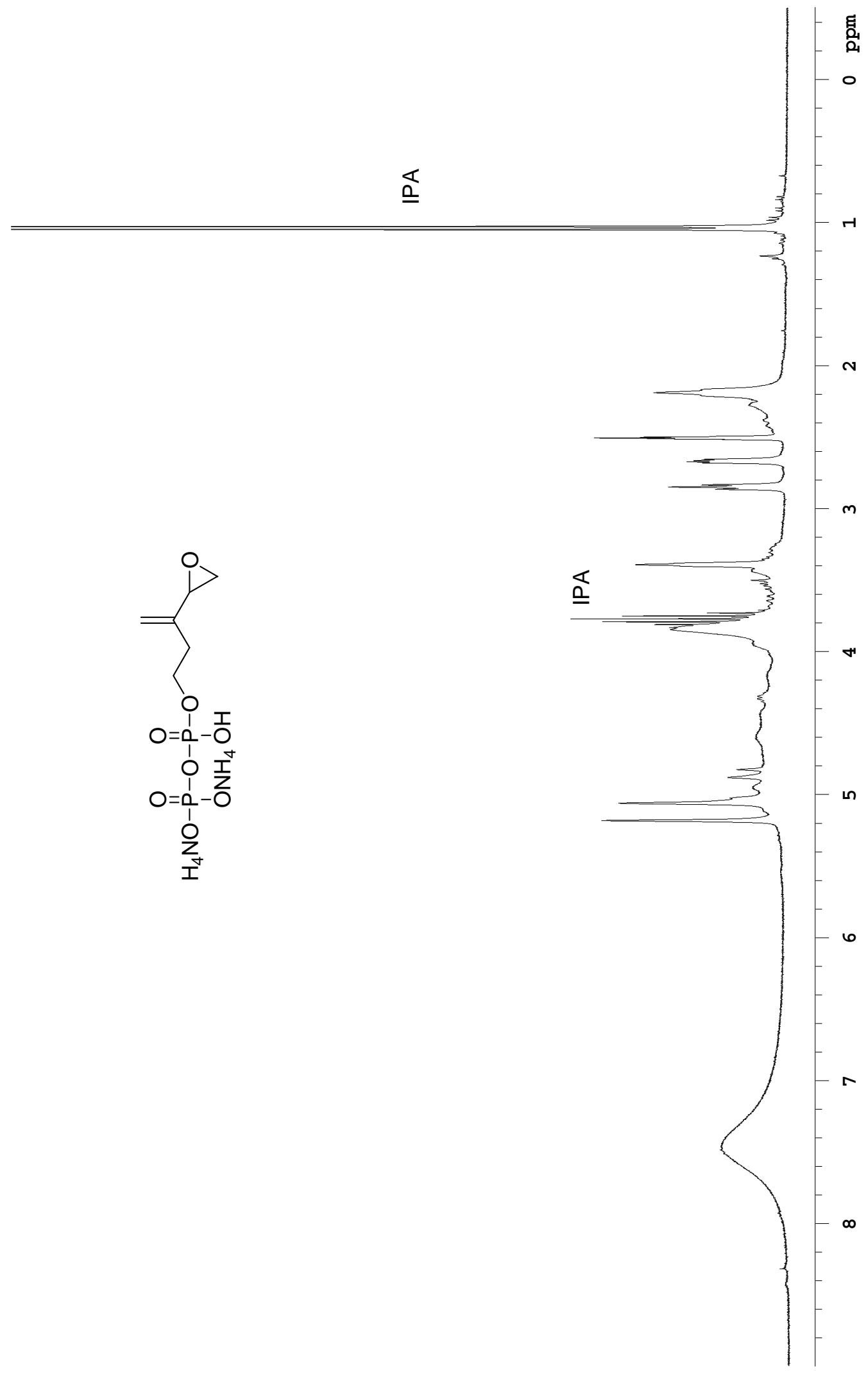




$$
1
$$




$$
11
$$

